\title{
Vliv terénní exkurze na modifikaci žákovských prekonceptů odborných pojmů
}

\author{
The Influence of the School Field Trip on the Modification of Preconception of \\ Scientific Terms
}

\author{
Zdeňka Chocholoušková1,*, Lenka Hajerová Müllerová ${ }^{1}$ \\ ${ }^{1}$ Západočeská univerzita v Plzni, Chodské nám. 1, 30614 Plzeň, Ceská republika; chochol@cbg.zcu.cz
}

Přínos terénní výuky je zjištován v realizovaném výzkumném šetření, které prostřednictvím kognitivního mapování umožňuje zaznamenat kvantitativní i kvalitativní změnu/posun v zastoupení (v četnosti) vybraných př́rodovědných pojmů. Žáci s hlubším zájmem o biologii, kteří absolvovali jednodenní výběrovou exkurzi, vypracovali konceptové mapy před a po exkurzi na základě předložených pojmů (se kterými se na exkurzi setkali). Pojmy žáci zároveň před i po exkurzi definovali. Na základě vysvětlení konceptových map před a po exkurzi byl hodnocen počet pojmů před a po exkurzi, jejich odborná správnost, počet a správnost propojení a počet křížových propojení mezi jednotlivými pojmy. Konceptové mapy byly analyzovány s použitím programů CMapTools a Gephi. U většiny žáků byl zaznamenán zásadní posun týkající se zvýšení počtu pojmů po exkurzi, přesnějšího zastrukturování, ale nebyl zaznamenán téměř žádný posun v použití propojovacích slov či vyjádření vazeb mezi jednotlivými pojmy.

The contribution of field trip is outlined in the realized research, which, through cognitive mapping, makes it possible to record a quantitative and qualitative change/shift in the content of selected scientific terms. Pupils with a deeper interest in biology who completed a one-day field trip developed concept maps before and after the field trip based on the terms presented (namely the ones they encountered during the field trip). At the same time, the pupils defined the terms before and after the excursion. Based on the verbal expression of terms and concept maps before and after the field trip, the number of terms before and after the excursion, the professionalism of their approach, the number and correctness of interconnections and the number of cross-links between terms were evaluated. Concept maps were analyzed using CMapTools and Gephi. Most pupils showed marked improvement after the field trip, having become familiar with more terminology and capable of more accurate structuring. However, there was hardly any shift in the use of linking words or expressing links between concepts.
Klíčová slova: exkurze, prekoncept, miskoncept, pojem, nadaný žák, žák s hlubším zájmem o obor, konceptová mapa.

Zasláno $11 / 2019$

Revidováno 2/2020

Prijato $5 / 2020$

\section{1 Úvod}

Nejobecnějším cílem vzdělávání je pozitivní změna žákovských dispozic (znalostí, dovedností, kompetencí). Změny v žákovských dispozicích ovšem nezačínají od nuly, ale navazují na již dosaženou výchozí úroveň. Proto k pojmenování těchto změn v následujícím textu užíváme termín modifikace a výchozí úroveň žákovských dispozic vyjadřujeme termínem prekoncept (podrobněji viz níže).

Zabýváme se vlivem výuky na modifikace prekonceptů u žáků 2. stupně ZŠ a gymnázií, kteř́i absolvovali terénní výuku biologie - jednodenní exkurzi zaměřenou na př́rodu a lidské aktivity CHKO Slavkovský les. Žáci z našeho výzkumného vzorku se v uplynulých třech letech aktivně účastnili krajských kol některé $\mathrm{z}$ přírodovědně zaměřených soutěží v Plzeňském kraji (olympiády nebo jiné přírodovědně orientované soutěže, např. Středoškolská odborná činnost, dále jen SOČ, EUCYS apod.). S ohledem na to můžeme u nich předpokládat přinejmenším motivovanost nebo i jiné aspekty nadání pro vzdělávací oblast přírodních věd. ${ }^{1}$

Naším výzkumným záměrem bylo získat konkrétní poznatky o vlivu terénní výuky biologie na modifikaci žákovských prekonceptů vědeckých pojmů. Prekoncepty mají strukturní povahu, nejsou tedy izolované (srov. Doulík \& Škoda, 2003, s. 178; Kohout et al., 2019, s. 26-34). Proto jsme ke zkoumání jejich modifikace využili konceptové mapy, které umožňují sledovat jak obsahové elementy, tak jejich strukturu, tj. jejich vzájemné vztahy.

\footnotetext{
${ }^{1}$ Podle Koncepce podpory rozvoje nadání a péče o nadané na období let 2014-2020 (2014, s. 4, dále jen Koncepce*) je v současnosti poskytována péče nadaným dětem, žákům a studentům především v rámci formálního vzdělávání na školách, služeb školských poradenských zařízení, zájmového vzdělávání a aktivit různých subjektů cíleně zaměřených na nadané (např. vysokých škol, Akademie věd ČR, nevládních neziskových organizací, některých firem a zahraničních subjektů). Tito žáci se často zapojují do různých oborově zaměřených soutěží.
} 


\section{Teoretická východiska}

\subsection{Problematika žákovských prekonceptů}

Hejný a Kuřina (2001, s. 159) považují za základní úkol učitele „motivovat žáky k aktivitě“, a mají tím na mysli aktivitu učební a poznávací. Klieme et al. (2009) v podobném smyslu vymezují konstrukt kognitivni aktivizace žáků směřující k hlubokému porozumění obsahu (cognitive activation and deep content). Úspěšnost kognitivní aktivizace žáků ve výuce závisí na mnoha okolnostech, ale její nutnou výchozí determinantou na straně žáka jsou tzv. prekoncepty ${ }^{2}$, které určují žákovskou motivovanost i předporozumění, s nimiž přistupuje ke vzdělávacímu obsahu. To znamená, že prostřednictvím žákovských prekonceptů se „filtruje“ působení učebního prostředí na žáka: ty rozhodují o tom, čemu bude žák rozumět lépe, čemu hưře, čím se bude chtít zabývat, co bude pro něj více, nebo méně zajímavé apod.

Termín prekoncept byl zaveden Piagetem k vysvětlení specifik raného dětského pojetí pojmů a intelektuálních operací s nimi spojených. Piaget charakterizoval prekoncept jako předobraz pojmu („předpojem“) zabarvený subjektivitou představy, senzomotorickými komponentami a ludickou symbolikou (Piaget, 1972, s. 224). Podle Slavíka et al. (2017, s. 156) je Piagetova původní charakteristika prekonceptu limitovaná tím, že nevymezuje prekoncept ve funkční relaci s konceptem. ${ }^{3}$ Proto navrhují pojímat prekoncept a koncept relačně:

V relačním pojetí lze vztah konceptu a prekonceptu pojímat šířeji na ose subjektivita vs. intersubjektivita. Tím lze lépe vystihnout a objasňovat procesy utváření, stvrzování, zpochybňování nebo vyjednávání významů, které probíhají na švu mezi konkrétní aktivitou subjektu zde a nyní a pravidelnými abstraktními systémy intersubjektivního významového zprostředkování na bázi jazyka a ustálených způsobů činnosti.

Z existence obsahových transformací vyplývá, že prekoncept a koncept musí sdílet nějakou část obsahu, ale koncept se přitom nemůže zcela rovnat prekonceptu - jejich obsah nemůže být úplně shodný. Zároveň musí být jejich vztah dynamický - během historie sociálního a kulturního konstruování a vyjednávání významů se obsah prekonceptů i konceptů může měnit, ač si zachovává totožnost, resp. identitu (srov. historické proměny konceptu taxonomie od doby Carla Linného k dnešní klasifikaci zahrnující analýzy DNA).

Aby obsah konceptu a prekonceptu mohl být v určitém směru ekvivalentní a zároveň odlišný a aby se mohl měnit, koncept i prekoncept musí mít strukturní a systémovou povahu. Doulík a Škoda (2003, s. 178) ji charakterizují pojmem zastrukturování prekonceptu:

Prekoncept [...] není nikdy izolovaný, ale vždy je určitým způsobem lokalizován v kognitivní mapě žáka. Jelikož tato začlenění se mohou mezi jednotlivými žáky i mezi jednotlivými prekoncepty značně lišit a mohou mít rozdílnou strukturu, hovoříme přesněji o zastrukturování, které lze do určité míry kvantitativně popsat.

Strukturní povahu prekonceptu i konceptu charakterizuje také Kohout et al. (2019, s. 26) pod pojmem mentální (konceptuální) schéma. ${ }^{4}$ Kohout et al. (2019, s. 26) zdůrazňují, že mentální či konceptuální schéma lze reprezentovat v podobě sémanticko-logické struktury - „sítě“. Tuto sít lze reprezentovat prostřednictvím konceptových map.

Citovaní autoři svými úvahami potvrzují, že prekoncept i koncept jsou obsahové celky uspořádané do sémantické a logické struktury svých částí. Tato struktura je hierarchická - tvoří systém - její prvky mohou být souřadné, nadřazené nebo podřazené. V tomto smyslu má koncept charakter pojmu (jazykové entity) a prekoncept je způsob jeho subjektivního uchopení (srov. Materna, 1995, s. 24-26).

Materna (1995, s. 11-13, 34-35 aj.; 1997) v návaznosti na Bolzana vysvětluje, že pojem (na rozdíl od představy) je abstraktní entita. Je to tedy ideální obsahová jednotka, která není závislá na jednotlivém subjektu, ale subjekt ji může reprezentovat jazykovými výrazy. To znamená, že výraz nebo struktura výrazů, kterou lze významově interpretovat, je vyjádřením pojmu nebo struktury pojmů. Pokud určitý

\footnotetext{
${ }^{2}$ Pod termín „prekoncept“ zde zahrnujeme i „spontánní pojem“. Mnohdy se užívají jako synonyma, ač je někdy účelné je rozlišovat. Spontánní pojmy, pojmy běžného života („žitějskije poňjatija“) jsou podle Vygotského (1978) tvořeny prostřednictvím praktické činnosti jedince. Doménou školství je osvojování systému vědeckých poznatků („naučnyje poňjatija“) předkládaných žákům ve vyučování. Doulík (2005, s. 9) poukazuje na rozdílnost mezi mimoškolním a školním prostředím, se kterým se lze při stavbě pojmu setkat. Vědecký pojem je v podmínkách školní výuky odvozován od obecného ke konkrétnímu, zatímco spontánní pojem vzniká naopak od konkrétního k obecnému.

${ }^{3}$ Pojetí prekonceptu jako „objektu v mysli“ podle citovaných autorů nedovoluje hlouběji rozebírat procesy utváření a vyjednávání významů, které probíhají na švu mezi subjektivním uchopením pojmu a intersubjektivně sdílenými pravidly jeho užívání.

4Adjektivem „mentální“ je položen důraz na subjektivní stránku obsahové jednotky (na její „uchopení“ subjektem), adjektivem „konceptuální“ na její stránku intersubjektivní, tj. na to, že je při komunikaci sdílena. „Mentální schéma“ lze chápat jako synonymum pojmu „kognitivní mapa žáka“ u Doulíka a Škody (2003, s. 178).
} 
výraz nebo výrazovou strukturu obsahově ztotožníme s jiným výrazem nebo strukturou, ř́íkáme, že jsou izomorfní a patří tedy stejnému pojmu nebo stejné pojmové struktuře (Slavík et al., 2017, s. 102-103).

Aby subjekt mohl svo̊j prekoncept vyjádřit výrazovou strukturou, musí ho umět zformulovat prostřednictvím reálného jednání bud’ jazykového (např. zformulovat smysluplnou větu) nebo intervenujícího (např. provést př́rodovědný experiment). Proto Kohout et al. (2019, s. 26) s oporou v citaci Goodmana a Elginové (2017) konstatují, že určité mentální či konceptuální schéma v mysli „znamená mít schopnost provádět odpovídající činnosti“, takže jeho „subjektivní existence se projevuje praktikováním dovedností vytvářet, posuzovat a revidovat řešení příslušných úloh". Vyjadřování a formulování prekonceptu tedy nemá výhradně jen jazykovou povahu, ale týká se obecně propojení mezi subjektivním uchopením určitého obsahu a jeho objektivní nebo intersubjektivní existencí.

V didaktice matematiky byl pro tento spojovací článek mezi subjektivitou a intersubjektivitou nebo objektivitou existence vzdělávacího obsahu navržen termín procept (srov. Gray \& Tall, 1994, s. 116; Hejný, 2003, s. 26; Janík et al., 2013, s. 170). ${ }^{5}$

Cílem výuky je, aby se prekoncepty žáků rozvinuly do poznatkově i činnostně hodnotnější úrovně a transformovaly se do funkční podoby proceptu - žákem zvládaného konceptu. Předpokladem toho je, že v učebním prostředí žáci spolu s učitelem transformují obsah prostřednictvím učebních úloh tak, aby se v jejich vědomí přetvářely a obohacovaly se prekoncepty, tj. aby se vytvářely nové obsahové struktury: nové „sítě“ významů (Slavík et al., 2017, s. 102-108). Mareš a Ouhrabka (2001, s. 419) hovoří o vytváření a vyjádření „subjektivní struktury vědění o určitém tématu“. Tento proces označujeme termínem instrumentalizace zkušenosti.

Instrumentalizace zkušenosti je kognitivní proces, v němž se žák učí s porozuměním zvládat symbolické a věcné nástroje - instrumenty - v příslušném oboru. Jak zdůvodnil Kvasz (2015, s. 16, 144-145) přirozená lidská zkušenost je od instrumentální zkušenosti oborů vzdálená - je oddělená mezerou a mnohdy dokonce „propastí“, kterou musí žáci překonat, a tak instrumentalizovat svou zkušenost. Ve výuce se instrumentalizace zkušenosti jeví jako postup od „žákovi blízkých“ výrazových struktur v jednání a komunikaci k strukturám „žákovi vzdáleným“ - k instrumentům oboru (Slavík et al., 2017, s. 37-39, 68).

Vzhledem k tomu, že prekoncept i koncept mají strukturní a systémovou povahu a závisejí na složitém kulturním kontextu, nemůže být instrumentalizace zkušenosti jednoduchou změnou, ale je to změna komplexní - je spojená s rozsáhlými restrukturacemi obsahu a s jeho přetvářením na různých hierarchických úrovních. Tento typ změn nazvali Slavík et al. (2017) relační změny. Relační změny jsou příznačné tím, že proměna dílčích prvků struktury obsahu v učebním prostředí a v myslích účastníků výuky je provázena pohybem v celé síti významových a logických souvislostí (Slavík et al., 2017, s. 22).

Relační změny jsou nutnou podmínkou pro instrumentalizaci zkušenosti, protože bez nich žáci nemohou postoupit od sobě „blízkých“ výrazových struktur ke strukturám „vzdáleným“, vztahujícím se k příslušnému oboru. Relační změny provázejí transformaci obsahu v učebním prostředí a svým charakterem podmiňují didaktickou kvalitu výuky. Uskutečňují se v učebním prostředí během komunikace a interakce učitele a žáků

na podkladě vzájemných vztahů (relací) mezi různými momenty intencionálního uchopení obsahu (např. vnímání, imaginace, mluvení, psychomotorického jednání) a na základě obsahových transformací mezi nimi. (Slavík et al., 2017, s. 132)

Při výkladu relačních změn tedy nejde jen o izolované prvky obsahu, ale musí se brát v úvahu celá soustava významových, logických a funkčních (akčních) vztahů, jimž mají žáci porozumět v příslušném kulturním, resp. oborovém kontextu. Ve výuce mají relační změny smysl tehdy, jestliže instrumentalizují žákovu zkušenost, a směřují tím k cíli výuky - zvládnout nové koncepty v kontextu určitého vzdělávacího oboru nebo vzdělávací oblasti. Žáci přitom musí začlenit nové poznání do své dosavadní zkušenosti. V psychologii a v oborových didaktikách je tento komplexní proces reprezentován termínem konceptuální změna.

\subsection{Pojmové (konceptové) mapování}

\subsubsection{Konceptuální změna}

Konceptuální změna je charakterizována jako proces, jehož prostřednictvím je dosavadní konceptová struktura kvalitativně i kvantitativně změněna nebo nahrazena novou (srov. Posner et al., 1982, s. 211-212). Tento strukturní posun se může týkat jednotlivce nebo společenství během historického vývoje poznání. V teorii konceptuální změny je kladen důraz na to, že změna je poměrně rozsáhlá a obsažná, takže zřetelně modifikuje dosavadní konceptovou strukturu.

\footnotetext{
${ }^{5}$ Tzv. elementární procept (elementary procept) má tři dimenze: (I) konstrukční proces (např. proces sčítání), (II) ideální objekt (pojem, koncept) vždy znovu utvářený tímto procesem (např. koncept čísla a součtu) a (III) výraz, který reprezentuje jak konstrukční proces, tak př́íslušný objekt (Gray \& Tall, 1994, s. 121).
} 
V návaznosti na předcházející výklad považujeme konceptuální změnu za druh relační změny, která směřuje k zvládnutí „z vnějšku“ (ve výuce) působícího konceptu, pod jehož vlivem žák kvalitativně anebo kvantitativně modifikuje svůj dosavadní prekoncept. Konceptuální změna se konkrétně projevuje modifikaci prekonceptu, tj. proměnou rozsahu, složitosti a kvality struktury prekonceptů, které jsou žáci schopni vyjádřit (např. pomocí konceptové mapy) a následně vysvětlovat na patřičné úrovni porozumění. Míra této modifikace může být větší, ve skocích, např. náhrada miskonceptu novou znalostí, i menší, dílčí doplnění nebo úprava.

Jak jsme uvedli, konceptuální změna se může týkat i společenství, přestože jejími reálnými nositeli zůstávají jednotliví aktéři. Proto ve vzdělávacím procesu je možné sledovat konceptuální změny i na úrovni žákovské skupiny, v níž žáci mohou získávat srovnatelnou zkušenost nebo ji spolu sdílet (např. ve školní třídě učitelé vědí, že jedna třída může „vědět více“ než jiná paralelní třída ve stejném ročníku). Také z tohoto hlediska jsme ke konceptuální změně přistupovali v našem výzkumu.

Vzhledem $\mathrm{k}$ výše rozebírané strukturní povaze prekonceptu a konceptu a s ohledem na neoddělitelné spojení mezi znalostí konceptu a př́ślušným jednáním je konceptuální změna spojená s re-strukturací dosavadních dispozic na různých úrovních a v různých dispozičních oblastech a v návaznosti na proměny v afektivní či motivační složce žákovy psychiky. Podle Vosniadou $(2007,2008)$ a di Sessy $(2007,2008)$ lze vymezit dvě perspektivy chápání konceptuální změny v teorii:

Klasická teorie konceptuální změny považuje poznávání za vysoce organizované v teoriích, schématech nebo rámcích. [...] jedna teorie velkého dosahu je nahrazena jinou, podobně jako probíhá paradigmatická změna ve vědě. [...] (Vosniadou, 2007, s. 52, 2008, s. 649). Na poznávání lze ale nahlížet jako na ekosystém volně provázaných prvků. [...] Je možné uvažovat i koexistenci opačných názorů v rámci poznatkového (eko)systému jedince (di Sessa, 2007, s. 42, 2008, s. 39).

U nás jsou tyto myšlenky k dispozici ve výkladu Dvořákové (2013, s. 103).

V tomto textu se nemůžeme hlouběji zabývat různými přístupy v teoriích konceptuální změny (bliže srov. Özdemir \& Clark, 2007). S oporou v textu Özdemira a Clarka (2007, s. 359) se naše pojetí opírá o přesvědčení, že koherence ve struktuře prekonceptu u jedince může $\mathrm{v}$ praxi mít $\mathrm{v}$ různých vývojových fázích různou míru a že konkrétní vzdělávací trajektorie u žáků mohou vyhovovat oběma teoretickým pojetím.

Jak uvádí Janík (2006, s. 35), výzkumy konceptuální změny přinesly poznatky o tom, že „v myslích žáků mohou vedle sebe existovat vzájemně si odporující představy“. Özdemir a Clark (2007, s. 360) v podobném smyslu podotýkají, že ve vývoji poznávání se doplňují koherentní a přechodové fáze. Strike a Posner (1982) upozorňují na to, že konceptuální změna předpokládá u žáka příznivé kognitivní nastavení, takže může uspokojivě proběhnout jen tehdy, jestliže sám žák není spokojen se svým prekonceptem a jestliže nově nabízené koncepty se mu jeví jako př́hodnější.

\subsubsection{Reprezentace konceptuální změny prostřednictvím konceptových map}

Zabýváme se modifikací prekonceptů žáků ve výuce z přírodovědné oblasti, konkrétně z oboru biologie. Výše jsme vysvětlili, že prekoncepty mají strukturní povahu a v tom se shodují s pojmy. Kromě toho jsme poukázali na to, že strukturu prekonceptu v žákově mysli můžeme poznávat pouze z vnějších žákovských projevů, v nichž se tato struktura ukazuje. Ideálním nástrojem pro zachycení struktury, tj. pro reprezentaci „zastrukturováni“" prekonceptu, jsou konceptové mapy.

Konceptové mapy jsou výtečným technickým prostředkem pro reprezentaci a zkoumání obsahových transformací ve výuce a při žákovském učení. Umožňují nahlédnout do struktury žákova prekonceptu, a podávají tak relativně ucelený výchozí obraz o myšlenkových postupech, hierarchii a utřídění prekonceptů, konceptů a popř. vzniku miskonceptů žáků. Informují o základních složkách poznání, struktuře a porozumění tématu, ukazují propojení jednotlivých poznatků do sémanticko-logických sítí (Ruiz-Primo \& Shavelson, 1996; Novak, 2010). Tím se mohou stát oporou pro další didaktické, př́ípadně výzkumné postupy, např. rozhovory, doplňující učební úlohy apod.

Konceptové mapy jsou grafickým znázorněním poznatků a poznatkových struktur (Strautmane, 2012). Proto je lze dobře využít pro usnadňování učení žákům ve výuce (Reiska \& Soika, 2015). Konceptové mapy kromě toho nabízejí různé možnosti pro uplatnění ve výzkumech žákovských pokroků během výuky, protože reprezentují aktuální stav vývoje žákova prekonceptu, takže mohou být podkladem k diagnostice jeho stavů.

Jednou z možností diagnostického využití v didaktickém výzkumu je zhodnocení efektivity a př́nosu různých výukových metod (Torkar et al., 2017). Konceptové mapy totiž neukazují pouze obsahové elementy, které žáci znají a umějí v mapě vyjádřit jako „uzly“, ale prostřednictvím „hran“ reprezentují i to, jak žáci své poznatky propojují (Iuli \& Helldén, 2004). Proto lze prostřednictvím konceptových 
map identifikovat žákovské miskoncepty (Van Zele et al., 2004) nebo analyzovat kvalitu zhodnocení žákova porozumění při didaktické transformaci obsahu z oborů, např. biologie (Novak \& Gowin, 1984; Jacobs-Lawson \& Hershey, 2002). Dalším využitím konceptových map je analýza výuky či výukových situací metodou 3A (Slavík et al., 2017, s. 294-338), kde tematická, konceptová i kompetenční vrstva jsou vyjádřeny v podobě konceptové mapy.

\subsection{Př́nos terénních exkurzí v prírodovědném (biologickém) vzdělávání}

Exkurze podle Vonkové (2011, s. 181) je řízená učební činnost žáků v autentickém přírodním prostředí. Je chápána spíše jako jednorázová aktivita, s cílem umožnit žákům, aby si utvořili přesnější představy, získali zkušenost z přímého styku s poznávanou realitou a aplikovali vědecké koncepce a procesy. Tento bezprostřední kontakt je emocionálním zážitkem z poznání, umocňuje vztah k předmětu poznání, dotváří teoretické poznatky ze školního prostředí (Cimer, 2007, s. 7), podporuje tvořivé myšlení žáků (dále viz Glynn \& Duit, 1995 Tytler, 2002; Patrick, 2010; Yassir \& Abeer, 2014).

Žáci z našeho výzkumného vzorku měli př́ležitost modifikovat své prekoncepty prostřednictvím terénní výuky - biologické exkurze. Proto se o tomto způsobu modifikování žákovských prekonceptů alespoň stručně zmíníme.

Vlivem terénní výuky, která umožňuje praktické propojení pojmů získaných během školní výuky, se zabývali Brehrendt a Franklin (2014). Autoři upozorňují, že pro maximalizaci propojení žákovských prekonceptů je třeba žákům umožnit vzájemnou diskusi. Žáci si mohou vzájemně vysvětlovat, pomáhat si v hledání řešení, podporovat se v dokončení úkolů, diskutovat o svém osobním porozumění tomu, co prožívají, vzájemně se učit. Autoři citují Rennie (2007, s. 126), která podotkla, že žáci, kteří se v rámci terénní exkurze zapojují v roli učitelů, často ve školní výuce nedosahují nejlepších výsledků.

Pauk (1981, s. 195) dělí exkurze na motivační (úvodní, které slouží k úvodu do dané problematiky), tematické (botanické, zoologické, mykologické, geologické apod.), shrnující (opakovací, přispívají k utřídění, upevnění, prohloubení a zopakování poznatků) a komplexní (aplikace vztahů v př́rodě, ale i multioborové pojetí vedoucí k propojení poznatků přírodních věd do sémantických struktur - biologie, zeměpisu, geologie, chemie, ale např. i fyziky).

Podobné dělení exkurzí uvádí Pavlasová (2014, s. 25-26); Pavlasová et al., 2015, s. 13), která třídí exkurze podle zvolených cílů a časového zařazení, a podle zaměření a náplně. Podle zvolených cílů a časového zařazení pak hovoří o exkurzích motivačních, které jsou zařazovány před probíráním daného učiva, průvodních, které jsou zařazovány v průběhu probíraného tématu a závěrečné, které jsou zaměřeny na využití teoretických poznatků v terénu a jsou zařazovány na závěr učiva tématu či tematického celku. Podle zaměření a náplně rozlišuje exkurze na monotematické (zaměřené na jeden obor - např. zoologické, geologické, mykologické apod.) nebo komplexní (zaměřené př́írodovědně, na více oborů), dále Chocholoušková a Hajerová (2019).

Myers a Jones (2018) upozorňují, že o exkurzi je třeba uvažovat nejen během její samotné realizaci, ale i ve fázích před a po exkurzi včetně aktivit s nimi spojených.

Mnoho studií se zabývá vlivem exkurzí na kognitivní a afektivní výstupy žáků (DeWitt \& Storksdieck, 2008). Komplexní výzkum dopadů exkurzí na kognitivní výsledky studentů, schopnost žáků interpretovat a popsat umění, dále pozitivní dopad exkurzí pro studenty se znevýhodněním ukazuje práce Greene, Kisida a Bowena (2014). Brady (1972, s. 77) upozorňuje na dřívější výzkumy (Crawford \& Grinstead, 1930; Fraser, 1939; Clark, 1943), z nichž vyplývá, že exkurze je efektivnějším způsobem výuky pro nadané studenty.

Rovněž v práci Whitesell (2015, s. 11) je zdơrazňován pozitivní vliv exkurzí na přírodovědné znalosti a dovednosti žáků středních škol. Sherf (1992, cit. podle Killermann 1998, s. 5) zjistil, že žáci po absolvování exkurze např. rozeznávali rostliny daleko lépe než žáci, kteří se stejné učivo učili pouze ve tř́íě. V závěru (s. 16) uvádí, že by učitelé měli podporovat žáky, aby uplatňovali získané znalosti a dovednosti v širších souvislostech. Kisiel (2005, s. 2) se zabýval výsledkem hodnocení učitelů, jichž 90 \% konstatuje, že exkurze považují za účinnou komplexní vyučovací metodu.

\section{Cíl šetření}

Hlavním cílem předložené studie bylo na základě provedené diagnostiky vstupních prekonceptů žáků/ účastníků exkurze, včetně jejich zastrukturování do konceptové mapy sledování konceptuální změny, (resp. rekonstrukce/modifikace žákovských vstupních představ.

Formulace výzkumných otázek:

1. Jak se projevil vzdělávací vliv jednodenní biologicky zaměřené exkurze $\mathrm{v}$ modifikaci prekonceptů žáků reprezentovaných rozsahem a sémanticko-logickou strukturou konceptových map? 
2. Jak se projevil vzdělávací vliv jednodenní biologicky zaměřené exkurze $\mathrm{v}$ modifikaci prekonceptů žáků s ohledem na odbornou kvalitu terminologie v konceptových mapách?

3. Jak se projevil vzdělávací vliv jednodenní biologicky zaměřené exkurze $\mathrm{v}$ modifikaci prekonceptů žáků s ohledem na opravu př́padných miskonceptů nebo zlepšení sémanticko-logické struktury prekonceptu reprezentovaného konceptovou mapou?

\section{Metodologie}

\subsection{Popis realizace exkurze}

Zvolené metodologické postupy prověřují účinnost terénní výuky biologie, v tomto př́padě exkurze, jako komplexní vyučovací metoda používaná k poznávání živé a neživé přírody, pochopení vztahů mezi organismy a prostředím a utváření postojů $\mathrm{k}$ ochraně přírody.

Rozebíraná jednodenní komplexní exkurze byla realizována v červnu 2018 a vedla do oblasti Chráněné krajinné oblasti Slavkovský les (CHKO), kde byla demonstrována co největší pestrost biotopů, využívání krajiny člověkem apod. (Hrouda \& Chocholoušková, 2013; Chocholoušková \& Hrouda, 2013). Byla lektorována botanikem a zoologem. Cílem exkurze bylo aplikovat konceptuální znalost strukturace odborných pojmů a procedurální znalost jejich uplatnění v praxi.

Exkurze začínala v Mariánských Lázních na Žižkově vrchu, kde je rovněž Geologický park umístěný do zachovalé bučiny s druhově bohatým podrostem, která je součástí Přírodní rezervace Žižkův vrch (PR Žižkův vrch). Zde byly demonstrovány jednotlivé druhy rostlin a živočichů typické pro bučiny, žáci pozorovali lupou charakteristické znaky jednotlivých taxonů, určovali rostliny a bezobratlé živočichy za pomoci určovacích klíčů, aktivně vyhledávali nové, jim neznámé druhy, sbírali rostliny a za pomocí smýkačky či sběrem do epruvet živočichy a podávali je lektorům, porovnávali a diskutovali mezi sebou, které druhy jsou typické pro ten či onen ekosystém, a které se zde vyskytují díky zásahu člověka, syntetizovali poznatky ze školy a praktické zkušenosti z terénu, z geologické mapy odvozovali geologické poměry a v terénu hledali stopy aktivní ochrany prrírody včetně ochrany území (označení chráněných území formou tabulí, červené pruhy na dřevinách, kdy předváděli, kdy jsou venku z rezervace, a kdy uvnitř, apod.). Společně $\mathrm{s}$ lektory opakovali formou řízené diskuse rozdělení chráněných území na velkoplošné a maloplošné.

Druhým navštíveným místem byla Přírodní rezervace Smrad’och (PR Smradoch) s rašeliništi, podmáčenými a rašeliníkovými smrčinami a mofetami s výrony suchého $\mathrm{CO}_{2}$ a $\mathrm{H}_{2} \mathrm{~S}$. Zde žáci měli za úkol objevit, po čem území zapáchá, starši žáci vysvětlovali mladším, jaké je chemické složení těchto látek. V autobusu proběhla diskuse o tom, co je to mofeta a venku měli žáci za úkol mofetu najít a charakterizovat.

Třetí zastávka byla nasměrována do Národních přírodních památek (NPP) Kř̌žzy a Upolínová louka. NPP Kř́žky představují lokalitu na hadcové skále s výskytem endemického rožce kư̌ičkolistého (Cerastium alsinifolium) a Upolínová louka je vlhká louka s řadou cenných druhů rostlin a živočichů. Zde žáci diskutovali o tom, jaký je rozdíl mezi reliktem a endemitem a v panelové diskusi s lektory ověřovali svá tvrzení.

Odsud exkurze pokračovala do zahrady zámku Mostov, do zámeckého parku s typickým uspořádáním dřevin od vzácných a exotických, které byly vysazeny bliže $\mathrm{k}$ zámku $\mathrm{k}$ domácím druhům, jež přecházely v okrajových partiích parku do volné př́rody. Žáci v zámeckém parku sbírali listy dřevin, analyzovali je, přiřazovali je ke dřevinám a v interiéru zámku hledali rostlinné a živočišné motivy, které zde byly použity. Pokoušeli se determinovat jednotlivé druhy. Poté se rozdělili do dvou skupin a první skupina se vžila do role zahradních architektů a navrhovala, jak by bylo možné park vylepšit, a druhá skupina byli oponenti $\mathrm{z}$ řad veřejnosti a kriticky se vyjadřovali k navrženým zásahům.

Další lokalitou byla Národní př́írodní rezervace Soos (NPR Soos), kde žáci navštívili muzeum a naučnou stezku věnovanou minerálním pramenům, slaniskům, rašeliništím, křemelinovému štítu apod. Císařský pramen, kde žáci ochutnávali kyselku, analyzovali sycení $\mathrm{CO}_{2}$, minerální vodu si nabírali do lahví a pozorovali, jak dlouho v ní vydrží $\mathrm{CO}_{2}$ a jak se za několik hodin změní její chute, zároveň pozorovali specifickou slanomilnou květenu v okolí pramene a syntetizovali své poznatky a formulovali teorie, čím je způsobeno, že je zde takto extrémní biotop; pramen Věra, který není pitný, avšak v jeho okolí je naprosto jiná květena, typická pro rašeliniště. Žáci porovnávali druhové složení okolí Císařského pramene a pramene Věra, syntetizovali dosavadní poznatky včetně toho, že někteří konstatovali „že něco podobného už jsme dnes viděli na Smrad’ochu“. Poslední zastávkou jednodenní exkurze byly Františkovy Lázně jako typické lázeňské město s parky a minerálními prameny, kde žáci zjištovali formou krátké ankety, proč sem návštěvníci přijiždějí, co je typické právě pro Františkovy Lázně, na naučných cedulích a panelech zjištovali složení a účinky zdejších minerálních vod a po nasednutí do autobusu porovnávali prameny na Soosu a ve Františkových Lázních. 


\subsection{Výzkumný vzorek}

Výzkum byl proveden se skupinou žáků, kteří prokázali zájem o př́rodní vědy, a tudíž jsme očekávali, že budou relativně lépe vybaveni jak v kognitivní, tak v afektivní stránce prekonceptu (srov. Doulík \& Škoda, 2003). Měli by tedy mít nejenom zájem na co nejlepším splnění úloh, ale také jejich prekoncepty by měly být (v porovnání s průměrnou populací) relativně bohatší. Proto by i modifikace prekonceptů měla být obsažnější a přinášet více informací.

Výběr našeho vzorku tedy můžeme charakterizovat (Pattona, 1990, s. 169, cit. podle Hendl, 2005, s. 154) jako účelový a intenzivní, tj. výrazně reprezentující zkoumaný fenomén (modifikace žákovského prekonceptu).

Na základě aktivního přihlášení samotných žáků na exkurzi byli do šetření zapojeni žáci druhého stupně ZS̆ a nižších gymnázií SS̆ narození v letech 2000-2004, kteří splňovali podmínku účasti v krajském kole olympiády z biologie, chemie, astronomie, ekologie nebo v krajském kole SOČ a jsou z Plzeňského nebo Karlovarského kraje. Takto bylo zařazeno celkem 11 respondentů.

Respondenti neprošli šetřením Pedagogicko-psychologické poradny Plzeňského či Karlovarského kraje za pomoci testových baterií pro nadané děti. Nahlížíme na ně jako na nadané jen s ohledem na jeden průkazný aspekt - hloubavý zájem o př́rodní vědy, a to účastí na přírodovědných olympiádách a SOČ. Jedná se tedy o žáky s hlubším zájmem o obor. Výzkumu se zúčastnilo šest dívek ve věkovém rozložení: dvě dívky 16 let, dvě dívky 15 let a dvě dívky 13 let a pět chlapců ve věku: jeden chlapec 16 let, dva chlapci 15 let, jeden chlapec 14 let a jeden chlapec 13 let.

\subsection{Metoda konceptového mapování}

Byla použita metoda konstrukce a vyhodnocení konceptových map, jako grafického, hierarchického vyjádření vztahu mezi koncepty použitelnému ke kvantitativnímu i kvalitativnímu porovnání znalostí žáků (Novak, 1990, 1998; Jacobs-Lawson \& Hershey, 2002). Využití konceptového mapování jako techniky pro sledování konceptuálních změn v biologii popisují ve své studii Wallace a Mintzes (1990). Tato metodologie byla rovněž prověřena a použita při mezinárodním výzkumu pedagogické hodnoty „serious games“ z ekologie rostlin (Torkar et al., 2017).

V české literatuře využití pojmového mapování ve vzdělávání na druhém stupni ZŠ popisuje Vaňková (2014. Do konceptové mapy vstupují pojmy, které mají definovaný obsah. Jednotlivé pojmy jsou propojovány vztahy za vzniku tvrzení: pojem - vztah - pojem. Vztahy vedoucí např́č strukturou jsou označovány jako křižové vztahy. Abstraktní pojmy bývají umístěny v hierarchii mapy výše, konkrétní pojmy níže. Pojmové mapy lze překreslit v prostředí CMAP Tools (IHMC - Institute for Humac and Machine Cognition, http://cmap.ihmc.us).

Pro vizualizaci sémanticko-logické sítě žáků byl použit software Gephi (Bastian, Heymann \& Jacomy, 2009). Ten vizualizuje uzly a hrany stejně jako jako konceptové mapy (diagramy), ale také (na rozdíl od konceptové mapy) je schopen vizualizovat směr i sílu hran (propojení jednotlivých uzlů) a frekvenci využití pojmů.

Využitím konceptových map a jejich zpracování prostřednictvím syntézy hromadných dat v „sítích“ (srov. Bruun \& Evans, 2018) se nabízí možnost sledovat modifikace prekonceptů nejenom u jednotlivců, ale u celé skupiny žáků. Můžeme proto, ovšemže s patřičnou opatrností jako při každém zobecňování, usuzovat na proměny, které byly vzdělávacím vlivem vyvolány v celém sledovaném „společenství myslí“ určité žákovské skupiny. Mohli bychom obrazně mluvit o posunu v „kognitivní atmosfére“e skupiny, protože došlo-li u více žáků např. k obohacení znalostí novou terminologií, je pravděpodobné, že se následně zvýší odborná kvalita komunikace v dané žákovské skupině.

Nástrojem sběru dat byl pracovní list, který žáci/účastníci exkurze vypracovali před exkurzí, v autobuse během cesty na exkurzi, a tentýž pracovní list, který vyplnili při zpáteční cestě. Se žáky byla nejprve diskutována problematika tvorby konceptových map. Žáci, kteří se zúčastnili šetření, byli dotazováni, zda pracují ve škole s konceptovými mapami. Většina z nich odpovídala, že se s konceptovými mapami již setkali, ale nepracují s nimi běžně. Byl jim tedy ještě připomenut postup tvorby konceptové mapy (Vaňková, 2014, s. 20-23, 40-41; Čapek, 2015, s. 336-337). Nejdříve žáci měli vysvětlit pět pojmů, se kterými se na exkurzi setkají: rašeliniště, slanisko, lázeňství, minerální vody, bučina. Tato aktivita měla sloužit k zjišsění prekonceptů žáků. Poté měli tyto pojmy spojit do konceptové mapy a rozššřit o pojmy, které se zadanými pojmy souvisí. Toto žáci prováděli před a po exkurzi, přičemž po exkurzi neměli $\mathrm{k}$ dispozici svoje data před exkurzí.

Poté byla ze všech konceptových map jednotlivých žáků v programu CMapTools (http://cmap.ihmx.us) vytvořena jedna souhrnná konceptová mapa před exkurzí a druhá po exkurzi.

Pojmové mapy byly hodnoceny strukturální metodou (Vaňková, 2014, s. 20-23, 40-41; Čapek, 2015, s. 336-337). Obě mapy byly porovnány z různých hledisek - počet pojmů celkem, počet propojení mezi 


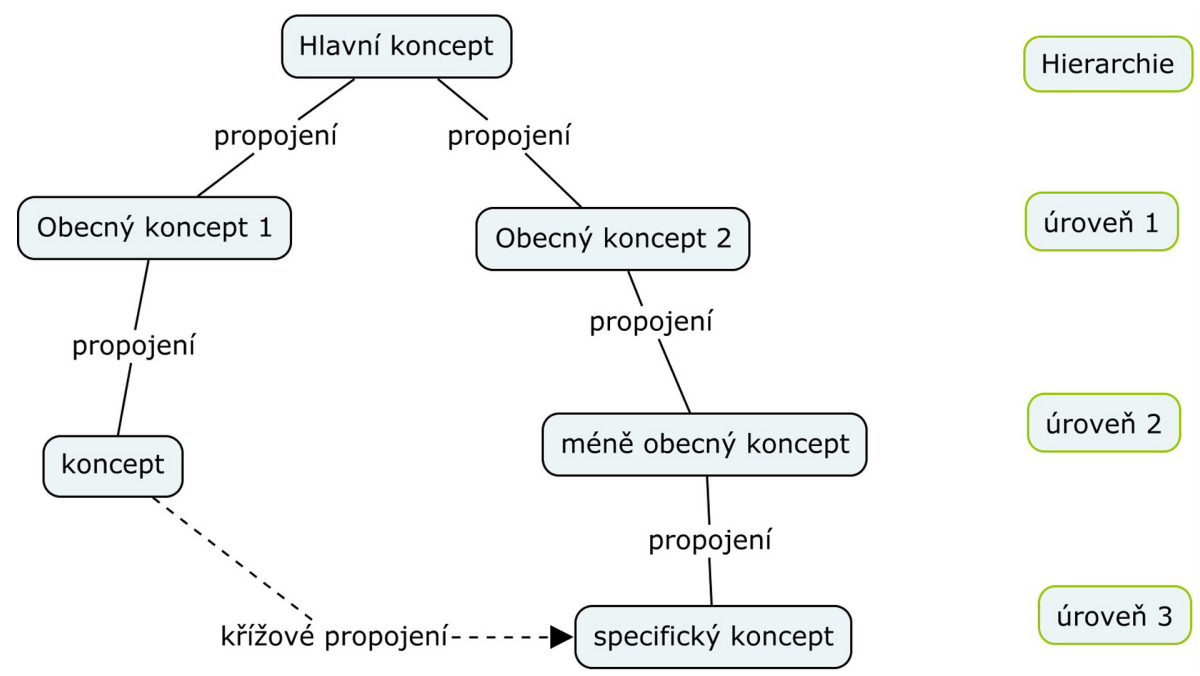

Obr. 1: Parametry sledované na konceptových mapách - počet propojení 5 , počet křížových propojení 1 , počet úrovní 3 (vytvořeno v programu CMapTools, http://cmap.ihmx.us)

pojmy, počet kř́řzových propojení mezi jednotlivými koncepty, počet konceptů a hlavní témata, počet miskonceptů, počet úrovní, počet nových pojmů (obr. 1).

Novak a Gowin (1984) pak přiřazuje jednotlivým komponentům mapy hierarchii a validitu tvrzení a přřrazuje jim určitou váhu. V této studii jsme porovnávali mapu před a po exkurzi a hodnotili jsme hierarchii a validitu tvrzení. Bylo porovnáno, jak se posunuly jednotlivé parametry před a pro exkurzi. Byla vyjádřena shoda v pojmech v obou mapách pomocí programu CmapTools.

Současně byly porovnávány konceptové mapy jednotlivých žáků před a po exkurzi, opět ze stejných hledisek, aby byl zachycen posun od prekonceptu k pojmu u jednotlivých žáků. Hlavní, nejvíce propracovaný koncept $\mathrm{v}$ konceptové mapě žáka, byl stanoven na základě celkového počtu pojmů, propojení a hierarchických úrovní (viz strukturální hodnocení podle Novak \& Gowin, 1984).

Dále byla porovnávána jednotlivá slovní vyjádření pojmů žáků před a po exkurzi, kdy k jednotlivým konceptům byly do tabulky vypsány pojmy, které žáci použili a červeně vyznačeny miskoncepty. Zde bylo použito pouze kvalitativní hodnocení výstupů, abychom prokázali vliv exkurze posun od prekonceptu k odbornému pojmu a odstranění miskonceptů. Použili jsme 4člennou stupnici: 0 - žák neodpověděl, 1 - úplný prekoncept (žák vysvětlil správně daný pojem), 2 - neúplný prekoncept (žák uvádí poznatky související s pojmem, ale vysvětlení není úplné), 3 - miskoncept (žák uvádí nesprávné vysvětlení pojmu).

Kódování žákovských odpovědí na uvedené čtyřstupňové škále bylo provedeno pouze jedním hodnotitelem, reliabilita kódování nebyla $\mathrm{v}$ rámci výzkumného šetření prováděna.

Byla využita i další technika zpracování a vizualizace dat pomocí softwaru Gephi (srov. Nohavová, 2018). Vzájemné porovnávání výsledků různých technik pro zpracování dat považujeme za uplatnění principu triangulace, která nabízí poznání zkoumaného jevu prostřednictvím porovnávání různých jeho aspektů (Švaříček et al., 2007, s. 204). Software Gephi poskytuje náhled na frekvenci užití pojmů v souhrnu všech zkoumaných konceptových map. Dospěje $\mathrm{k}$ tomu prostřednictvím výpočtů opřených o matici, která zachycuje celkové množství uzlů a jejich vztahů v mapách všech respondentů.

Pro vizualizaci pomocí softwaru Gephi byly vytvořeny matice pojmů před a po exkurzi, které obsahují všechny pojmy, jež se vyskytly v konceptových mapách. Všechny pojmy jsou uvedeny jak v řádcích, tak ve sloupcích. Směr od pojmu A k pojmu B $(A \rightarrow B)$ je vyjádřen vztahem řádek-sloupec. Když je směr oboustranný, opakuje se dvojice pojmů opět řádek-sloupec. Když je spojeno několikanásobně více pojmů, opakuje se vztah pro každou dvojici (obr. 2).

\begin{tabular}{|c|c|c|c|c|}
\hline & $\mathrm{A}$ & $\mathrm{B}$ & $\mathrm{C}$ & $\mathrm{D}$ \\
\hline $\mathrm{A}$ & & $/ \times$ & $/ \times$ & $/ \times$ \\
\hline $\mathrm{B}$ & $\times$ & & $/ \times$ & $/ \times$ \\
\hline $\mathrm{C}$ & $\times$ & $\times$ & & \\
\hline $\mathrm{D}$ & $\times$ & $\times$ & & \\
\hline
\end{tabular}

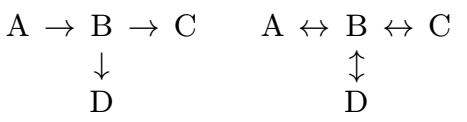

Obr. 2: Znázornění zaznamenávání pojmů do pojmové matice pro zpracování v softwaru Gephi

Při vyhodnocení velikost písmen odpovídá frekvenci užití pojmů v konceptových mapách žáků a propojení těchto pojmů s ostatními podřadnými pojmy v hierarchii pojmů. Miskoncepty nebyly zahrnuty do matice $\mathrm{v}$ plné ššři, tj. pokud se pojem vázal např. ke slanisku, byl ještě vzdáleně propojen s lázeňstvím, ale toto propojení bylo chybné, nebyl počítán opakovaně. Stejně tak např. pojem slanisko - př́má vazba 
k málo dřevin, ale vzdáleně bylo propojeno s pojmem lázeňství, čímž by vznikl miskoncept, tudíž lázeňství nebylo započítáváno opakovaně, jedná se o jinou modalitu pohledu. Propojovací (funkční) slovesa byla nahrazena př́idavnými jmény a započítána do matice - např. minerální prameny $\rightarrow$ ty se využívají $\rightarrow$ lázeňství, bylo počítáno jako minerální prameny $\rightarrow$ využití $\rightarrow$ lázeňství, aby nedocházelo ke ztrátě či zkreslování pojmů a vazeb.

\section{Výsledky výzkumu}

\subsection{Vyjádření pojmu před a po exkurzi}

Vstupní prekoncepty žáků reprezentované konceptovou mapou před exkurzí (tab. 1) ukazují na správnou představu o tom, co je rašeliniště, konstatují, že je tam rašelina, kyselá půda, vlhko, rašeliníky, rosnatky, tučnice, borůvky. Tři žáci řeší i vznik rašeliniště - nahromaděním odumřelých těl rostlin. Dva žáci popisují využití rašeliny pro zábaly, koupele a hnojení. Dva žáci mají představu o tom, kde se rašeliniště vyskytují (Soos, Tříjezerní slat). Byl zaznamenán pouze jeden zásadní miskoncept, a to záměna vzniku rašeliny se vznikem černého uhlí.

Pojem slanisko činil žákům daleko největši potíže. Dokonce v jednom prŕpadě se žák vůbec nepokusil o vysvětlení. Šest žáků se omezilo na konstatování, že je to oblast se slanými půdami. Pět žáků uvedlo jinou odpověd'.

Lázeňství je obecně známým pojmem a nečinilo ani problémy při vysvětlování před ani po exkurzi. U dvou žáků byly zaznamenány dva miskoncepty vztahující se $\mathrm{k}$ léčivým pramenům a mofetám.

Minerální vody podobně jako pojem lázeňství nečinily problémy vysvětlit, přestože někdy nebyla vysvětlení přesná (někdy jsou uvedeny rozpuštěné minerály namísto minerální látky - nahližíme na tuto skutečnost tedy tak, že některé minerály jsou rozpustné a jejich rozpuštěním mohou vznikat rozpuštěné minerální látky). Dva žáci správně lokalizovali, kde se minerální vody v ČR nacházejí. Jeden žák se o vysvětlení pojmu před exkurzí nepokusil.

Bučina byla vysvětlována před exkurzí jako bukový les, jen v jednom př́ípadě byl zaznamenán miskoncept (tab. 1: C). Žák G a H uvádí nepřesné odpovědi, místo, kde rostou buky, mǔže být i skupinka buků $\mathrm{v}$ parku, v druhém př́padě není uvedeno, že tam rostou buky.

Po exkurzi (tab. 2) došlo u pojmu rašeliniště k mírnému zhoršení, všichni žáci však smysluplněji popisují vznik rašeliny, avšak ve snaze se přesně vyjádřit se dva žáci dopustili nepřesnosti. U jednoho žáka vzniká nový miskoncept, kdy zaměňuje proces rašelinění (pomalý rozklad organické hmoty při nadbytku vody a nedostatku vzduchu), hnití (rozklad organické hmoty za nedostatečného př́stupu vzduchu) a tlení (rozklad organické hmoty za přístupu vzduchu). $\mathrm{V}$ jednom př́padě je chybně datován vznik rašeliništ. U dvou žáků se zvýšil počet typických zástupců pro rašeliniště (klikva bahenní, suchopýry). Všichni žáci po absolvování exkurze přesněji vymezují pojem rašeliniště (tab. 1,2).

U pojmu slanisko byly po exkurzi zaznamenány dva miskoncepty, který uváděl výskyt zmenšených forem rostlin (nanismů), endemický rožec, což není vůbec typické pro slaniska, ale pro hadcové skalky, které byly během exkurze také navštíveny. $\mathrm{V}$ jednom př́padě je patrná snaha po exkurzi uplatnit nabyté poznatky, zpřesnit a rozšriřit své tvrzení. Žák však uvádí pouze rodový název skřípinec, který zahrnuje více druhů a ty nemusí být svým výskytem vázány na slaniska. V NPR Soos byl demonstrován skř́íinec Tabernaemontanův (Schoenoplectus tabernaemontani). V jednom př́padě je uvedena skř́pina, což vzniklo patrně na základě záměny rodových názvů skřípinec a skřípina, skř́íina lesní (Scirpus sylvatica) není pro slaniska typická. Také je $\mathrm{v}$ jednom př́padě popisován výskyt náletových dřevin ${ }^{6}$, což není to typické pro slaniska, ale pro jakýkoliv biotop bez zastoupení dřevin. Došlo k mírnému zlepšení (o jednoho žáka více správných odpovědí), ovšem evidentně zde nedošlo vůbec $\mathrm{k}$ zastrukturování pojmu.

Ve vysvětlení pojmu lázeňství došlo po exkurzi k mírnému zlepšení, žáci používali k vysvětlení pojmu poznatky nabyté během exkurze. Tyto poznatky nepropojili s prekoncepty (např. radon a Krušné hory po exkurzi nebyly zmiňovány). Po exkurzi došlo $\mathrm{k}$ výraznějšímu zastrukturování pojmu a propojení s minerálními prameny a rašelinou.

Pojem minerální vody po exkurzi tři žáci formulovali správně, osm ne zcela přesně, všichni žáci odpovídali. V jednom případě odpověd’ zněla: „,vody obohacené“, ale není už uvedeno čím. Pravděpodobně by bylo potřeba ještě poznatky upevnit dalším opakováním.

Bučina jako pojem zaznamenala posun u žáků jak v množství informací, tak v jejich zastrukturování (cf. tab. 1, 2). Bylo zachyceno pět miskoncepů u čtyř žáků, např. květin a bylin - což v tomto pojetí, tj. jako podrost bukového lesa je totožné, pak jírovec jako typický druh pro bučiny, což je ve skutečnosti nepůvodní druh ČR, kolotočnice namísto kolotočník, dále naprosto mylná informace o hadovci (namísto hadci) a lepším uvolňováním minerálních látek. Ve skutečnosti na serpertinitu je uvolňování živin problematické

\footnotetext{
${ }^{6} \mathrm{~S}$ výskytem náletových dřevin se lze v NPR Soos setkat.
} 
Tab. 1: Vysvětlení pojmů žáky před exkurzí

Legenda: A-K - jednotliví žáci, 0 - žák neodpověděl, 1 - úplný prekoncept, 2 - neúplný prekoncept, 3 - miskoncept - jsou vyznačeny kurzívou

\begin{tabular}{|c|c|c|c|c|c|}
\hline$\frac{\text { pojem }}{\text { žák }}$ & rašeliniště & slanisko & Lázeňství & minerální vody & Bučina \\
\hline A & $\begin{array}{l}1 \text { rašelina, mokro, } \\
\text { Soos, možnost } \\
\text { propadnutí se, kyselá } \\
\text { půda }\end{array}$ & $2 \mathrm{NaCl}$ & $\begin{array}{l}1 \text { lázně, KV, KV } \\
\text { kraj, zábaly } \\
\text { (rašelina), léčení } \\
\text { onemocnění }\end{array}$ & $\begin{array}{l}1 \text { vřídlo, Rudolfův } \\
\text { pramen, teplá } \\
\text { minerální voda, } \\
\text { Magnesia, Mg, S, } \\
\text { Karlovarsko }\end{array}$ & $\begin{array}{l}1 \text { místo (kopec, les), } \\
\text { kde rostou jen buky }\end{array}$ \\
\hline $\mathrm{B}$ & $\begin{array}{l}1 \text { místo pokryté } \\
\text { rašeliníkem } \\
\text { obecným - jeho části } \\
\text { vytvářejí rašeliniště }\end{array}$ & 0 & $\begin{array}{l}1 \text { činnost lidí ve } \\
\text { městech s léčivými } \\
\text { prameny, pomoc } \\
\text { lidem s nemocemi, } \\
\text { např. pohybové } \\
\text { ústrojí }\end{array}$ & $\begin{array}{l}2 \text { voda s obsahem } \\
\text { minerálů, vitamínů, } \\
\text { př. } \mathrm{Mg}, \mathrm{K}, \mathrm{Ca}\end{array}$ & $\begin{array}{l}1 \text { místo s vysokým } \\
\text { výskytem buků } \\
\text { s různými rostlinami }\end{array}$ \\
\hline $\mathrm{C}$ & $\begin{array}{l}1 \text { rašeliník rostoucí } \\
\text { nahoru, odumírajíc } \\
\text { ze spodu, strašidelný } \\
\text { příběh, který se } \\
\text { odehrává v rašeliništi }\end{array}$ & $\begin{array}{l}1 \text { rozsáhlá oblast } \\
\text { se slanou půdou }\end{array}$ & $\begin{array}{l}2 \text { náš školní výlet do } \\
\text { Mariánek }\end{array}$ & $\begin{array}{l}2 \mathrm{Mg} \text { a naše paní } \\
\text { učitelka Che }\end{array}$ & $\begin{array}{l}3 \text { bučící krávu na } \\
\text { louce, květiny }\end{array}$ \\
\hline $\mathrm{D}$ & $\begin{array}{l}1 \text { porosty rašeliníků, } \\
\text { pod nimiž je rašelina } \\
\text { v mokřadu, rostou } \\
\text { zde rosnatky, tučnice } \\
\text { atd. }\end{array}$ & $\begin{array}{l}3 \text { stráň, svití zde } \\
\text { slunce }\end{array}$ & $\begin{array}{l}1 \text { vytváření lázní } \\
\text { a vydělávání na nich }\end{array}$ & $\begin{array}{l}2 \text { voda, jež má } \\
\text { vysoký obsah } \\
\text { minerálů }\end{array}$ & $\begin{array}{l}1 \text { bukový les, shnilé } \\
\text { popadané stromy, } \\
\text { mloci }\end{array}$ \\
\hline $\mathrm{E}$ & $\begin{array}{l}1 \text { rašeliník, rosnatka } \\
\text { okrouhlolistá, Soos, } \\
\text { Tř́jezerní slaț, } \\
\text { borůvky, žlutásek } \\
\text { borůvkový }\end{array}$ & $\begin{array}{l}1 \text { okraje silnic, } \\
\text { slanobýl, oblast } \\
\text { nasycená } \mathrm{NaCl} \\
\text { a } \mathrm{KCl}\end{array}$ & $\begin{array}{l}1 \text { lázně, rašelina, } \\
\text { radon, Krušné Hory, } \\
\text { Karlovy V. }\end{array}$ & $\begin{array}{l}1 \text { Vincentka, } \\
\text { Luhačovice, Mattoni, } \\
\text { KV, vřídlo }\end{array}$ & 1 buk, listnatý les \\
\hline 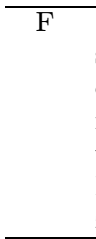 & $\begin{array}{l}1 \text { místo, kde se na } \\
\text { sebe navrstvily } \\
\text { odumřelé části } \\
\text { rostlin, za vzniku } \\
\text { této kyselé půdy. } \\
\text { Rašelina - různé } \\
\text { zábaly a koupele. }\end{array}$ & $\begin{array}{l}2 \text { zde se mohou } \\
\text { objevovat různé } \\
\text { min. prameny, je } \\
\text { zde specifická } \\
\text { půda }\end{array}$ & $\begin{array}{l}\text { 1 souvisí s léčivými } \\
\text { prameny, zaměřuje } \\
\text { se na lidi, kteří mají } \\
\text { nějaký zdravotní } \\
\text { problém a pomocí } \\
\text { různých kůr se snaží } \\
\text { pomoci }\end{array}$ & $\begin{array}{l}1 \text { voda s obsahem } \\
\text { min. l obvykle } \\
\text { vyvřívající ze země } \\
\text { ve formě různých } \\
\text { pramenů }\end{array}$ & $\begin{array}{l}1 \text { les zastoupený } \\
\text { zejména buky }\end{array}$ \\
\hline $\bar{G}$ & $\begin{array}{l}1 \text { místo, kde roste } \\
\text { rašeliník a vytváří } \\
\text { vrstvy, které jsou } \\
\text { vhodné pro hnojení }\end{array}$ & $\begin{array}{l}1 \text { zamokřená } \\
\text { půda, která } \\
\text { obsahuje větší } \\
\text { množství solí }\end{array}$ & $\begin{array}{l}1 \text { pracovní oblast, } \\
\text { kde pracují lidé, } \\
\text { kteří pomáhají } \\
\text { druhým lidem } \\
\text { s potížemi tím, že } \\
\text { jim zprostředkují } \\
\text { využití léčebných } \\
\text { pramenů a růz. } \\
\text { procedur }\end{array}$ & $\begin{array}{l}1 \text { vody obohacené } \\
\text { o min. látky, které } \\
\text { mohou působit } \\
\text { léčebně pro lidské } \\
\text { tělo, jsou to tvrdé } \\
\text { vody }\end{array}$ & $\begin{array}{l}2 \text { les, který je častý } \\
\text { v ČR, a rostou } \\
\text { v něm jehličnaté } \\
\text { i listnaté stromy }\end{array}$ \\
\hline $\mathrm{H}$ & $\begin{array}{l}1 \text { kyselé prostředí, } \\
\text { rašeliníky, břízy, } \\
\text { bažinaté prostředí se } \\
\text { zrádnými mokřady }\end{array}$ & $\begin{array}{l}1 \text { místo, kde je } \\
\text { silně slané } \\
\text { prostředí, } \\
\text { prameny } \\
\text { s obsahem vody } \\
\text { vyschnou } \\
\text { a nechají půdu } \\
\text { slanou }\end{array}$ & $\begin{array}{l}1 \text { lázně k rehabilitaci } \\
\text { lidí, léčebné } \\
\text { procedury (termální } \\
\text { a minerální } \\
\text { prameny), lázeňská } \\
\text { městy, dlouhá tradice } \\
\text { díky pramenům }\end{array}$ & $\begin{array}{l}1 \text { vody s vyšším } \\
\text { obsahem rozp. min, } \\
\text { mohou mít léčebné } \\
\text { účinky, ale mohou } \\
\text { způsobit i střevní } \\
\text { potíže }\end{array}$ & $\begin{array}{l}2 \text { místo, kde rostou } \\
\text { buky }\end{array}$ \\
\hline 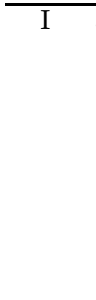 & $\begin{array}{l}3 \text { místo, jehož vznik } \\
\text { zapříčinili stromy } \\
\text { (např. přesličky), } \\
\text { rostoucí } \\
\text { v prvohorách, které } \\
\text { napadaly v minulosti } \\
\text { do bahna (rašelina), } \\
\text { dnes využivána jako } \\
\text { uhlí }\end{array}$ & $\begin{array}{l}\text { rozsáhlejší } \\
\text { území pokryté } \\
\text { několika skalami } \\
\text { - vyvýšenina }\end{array}$ & $\begin{array}{l}2 \text { oblast v okolí lázní } \\
\text { s výskytem léčivých } \\
\text { pramenů, průmysl } \\
\text { zabývající se } \\
\text { zlepšováním kvality } \\
\text { daných lázní }\end{array}$ & $\begin{array}{l}2 \text { vody pramenící } \\
\text { v okolí lázní (někt. } \\
\text { léčivé prameny), } \\
\text { s vyš. obsahem } \\
\text { minerálů }(0,8 \mathrm{mg} / 1)\end{array}$ & $\begin{array}{l}1 \text { lokalita, na kt. } \\
\text { rostou převážně } \\
\text { buky = bukové lesy }\end{array}$ \\
\hline$\overline{\mathrm{J}}$ & $\begin{array}{l}1 \text { místo, kde roste } \\
\text { rašeliník - vzniká } \\
\text { rašelina }\end{array}$ & $\begin{array}{l}1 \text { místo, kde je } \\
\text { v půdě a vodě } \\
\text { normálně vys. } \\
\text { konc. solí }\end{array}$ & $\begin{array}{l}1 \text { léčebné kůry (např. } \\
\text { léčba pohyb. ústrojí, } \\
\text { obezity, atd) }\end{array}$ & $\begin{array}{l}2 \text { vody s vyšším } \\
\text { obsahem někt. } \\
\text { minerálů, než je } \\
\text { obvyklé }\end{array}$ & 1 les složený z buků \\
\hline $\bar{K}$ & $\begin{array}{l}1 \text { oblast s výskytem } \\
\text { rašeliny }\end{array}$ & $\begin{array}{l}1 \text { oblast se slan. } \\
\text { půdami }\end{array}$ & $\begin{array}{l}1 \text { oblast } \mathrm{s} \text { léčbou } \\
\text { minerálními } \\
\text { prameny }\end{array}$ & 0 & 1 bukový les \\
\hline
\end{tabular}


Tab. 2: Vysvětlení pojmů žáky po exkurzi

Legenda: A-K - jednotliví žáci, 0 - žák neodpověděl, 1 - správné vymezení pojmu, 2 - neúplné vymezení pojmu, 3 miskoncept - jsou vyznačeny kurzívou

\begin{tabular}{|c|c|c|c|c|c|}
\hline$\frac{\text { pojem }}{\text { žák }}$ & rašeliniště & Slanisko & Lázeňství & minerální vody & bučina \\
\hline A & $\begin{array}{l}3 \text { místo porostlé } \\
\text { rašeliníkem, který na } \\
\text { povrchu dorůstá a pod } \\
\text { povrchem uhnivá - } \\
\text { rašelina }\end{array}$ & $\begin{array}{l}1 \text { místo } \\
\text { vykrystalizování } \\
\text { soli (Glauberovy) }\end{array}$ & $\begin{array}{l}1 \text { obor zabývající } \\
\text { se léčbou nemocí } \\
\text { lázeňskou formou } \\
\text { (koupele, zábaly) }\end{array}$ & $\begin{array}{l}2 \text { voda s vyšším } \\
\text { obsahem minerálů } \\
(\mathrm{Fe}, \mathrm{Mg}, \mathrm{K})(\text { až } \\
2000 \mathrm{mg} / \mathrm{l})\end{array}$ & $\begin{array}{l}2 \text { les s buky, kde } \\
\text { rostou hlavně buky, } \\
\text { roste zde pod stromy } \\
\text { mnoho květin a bylin }\end{array}$ \\
\hline $\mathrm{B}$ & $\begin{array}{l}1 \text { místo, které vzniklo } \\
\text { ve čtvrtohorách } \\
\text { z rašeliníku, stále tyto } \\
\text { procesy pokračují }\end{array}$ & 0 & $\begin{array}{l}1 \text { medicína, léčivé } \\
\text { prameny }\end{array}$ & $\begin{array}{l}2 \text { voda s vyšším } \\
\text { obsahem minerálů, } \\
5 \mathrm{mg} / \mathrm{l})\end{array}$ & $\begin{array}{l}1 \text { místo s hlavními } \\
\text { stromy - buky }\end{array}$ \\
\hline $\mathrm{C}$ & $\begin{array}{l}1 \text { zarostlá vodní } \\
\text { plocha rašeliníkem }\end{array}$ & 1 slaná plocha půdy & $\begin{array}{l}1 \text { léčení } \\
\text { minerálními } \\
\text { vodami, bahnem }\end{array}$ & $\begin{array}{l}2 \text { vody se } \\
\text { zvýšeným } \\
\text { obsahem minerálů }\end{array}$ & 1 les $z$ buků \\
\hline $\mathrm{D}$ & $\begin{array}{l}1 \text { porosty rašeliníku, } \\
\text { kt. nekonečně roste, } \\
\text { dole se rozkládá, } \\
\text { nahoře přirůstá, } \\
\text { rozložený rašeliník } \\
\text { tvoří rašelinu, } \\
\text { masožravky, klikva } \\
\text { bahenní, suchopýry }\end{array}$ & $\begin{array}{l}3 \text { světlé mokré } \\
\text { stráně, skřipince }\end{array}$ & 1 vytváření lázní & $\begin{array}{l}2 \text { vody se zvýš. } \\
\text { obsahem minerálů, } \\
\text { více typů, léčivé } \\
\text { dovednosti, } \\
\text { alespoň } 20 \mathrm{~g} \text { až } \\
2000 \mathrm{~g} / \mathrm{l}\end{array}$ & $\begin{array}{l}2 \text { bukový les } \\
\text { s hojným podrostem, } \\
\text { vraní oko čtyřlisté, } \\
\text { svízel vonný, } \\
\text { kolotočnice zdobná, } \\
\text { devětsil bílý, silenka } \\
\text { dvoudomá, šţavel } \\
\text { kyselý }\end{array}$ \\
\hline $\mathrm{E}$ & $\begin{array}{l}1 \text { podmáčená oblast } \\
\text { s mechem rašeliníkem } \\
\text { a kyselomilnými } \\
\text { rostlinami }\end{array}$ & $\begin{array}{l}1 \text { podmáčená oblast } \\
\text { s vývěrem slané, } \\
\text { minerální vody }\end{array}$ & $\begin{array}{l}1 \text { využívání } \\
\text { minerálních vod na } \\
\text { léčení lidí }\end{array}$ & $\begin{array}{l}2 \text { voda s vysokým } \\
\text { obsahem minerálů }\end{array}$ & 1 monokultura buků \\
\hline $\mathrm{F}$ & $\begin{array}{l}2 \text { místo, kde za } \\
\text { nepřístupu vzduchu } \\
\text { „hnijí“ odumřelé části } \\
\text { rostlin, zejména pak } \\
\text { rašeliník - konec } \\
\text { průběžně odumírá, ale } \\
\text { roste pořád - výskyt } \\
\text { rosnatky okrouhlolisté }\end{array}$ & $\begin{array}{l}2 \text { oblast (lokalita) } \\
\text { s kyselejší půdou, } \\
\text { rostou zde náletové } \\
\text { dřeviny (břiza, } \\
\text { vrba), výskyt } \\
\text { vodních ptáků, } \\
\text { rostliny zvyklé na } \\
\text { tento druh půdy } \\
\text { (skřipina) }\end{array}$ & $\begin{array}{l}1 \text { nejvíce } \\
\text { zastoupeno v SZ } \\
\text { Čechách, mnoho } \\
\text { léčivých pramenů, } \\
\text { využití rašeliny }\end{array}$ & $\begin{array}{l}1 \text { SZ Cechy, ze } \\
\text { země vyvěrají } \\
\text { prameny bohaté } \\
\text { na min. látky } \\
\text { ( } 5 \mathrm{mg} / 1 \text { - } \\
\text { minimálně }), \text { mají } \\
\text { léčivé účinky }\end{array}$ & $\begin{array}{l}3 \text { les, kde jsou } \\
\text { zejména buky (dub, } \\
\text { jírovec, javor), u nás } \\
\text { nemají tak dobrý } \\
\text { podrost, v okolí ML } \\
\text { ano, díky hornině - } \\
\text { hadovci - lep̌̌i } \\
\text { uvolňování min. } \\
\text { látek }\end{array}$ \\
\hline $\mathrm{G}$ & $\begin{array}{l}1 \text { zamokřené místo, } \\
\text { kde neroste jenom } \\
\text { rašeliník, ale i další } \\
\text { rostliny (vřes), } \\
\text { brusnice borůvka, } \\
\text { suchopýr pochvatý } \\
\text { a vytváří se zde } \\
\text { rašelina }\end{array}$ & $\begin{array}{l}1 \text { zamokřené místo, } \\
\text { pro které je typický } \\
\text { obsah solí v půdě - } \\
\text { žijí zde rostliny } \\
\text { a živočichové } \\
\text { přizpůsobení těmto } \\
\text { podmínkám } \\
\text { (zasolení dochází } \\
\text { díky protékání min. } \\
\text { pramenů) }\end{array}$ & $\begin{array}{l}1 \text { balneologie - } \\
\text { obor, kt. se zabývá } \\
\text { min. prameny } \\
\text { (vodami), a jejich } \\
\text { úč. na lidský org. }\end{array}$ & $\begin{array}{l}1 \text { tvrdé vody, kt. } \\
\text { obsahují } \\
\text { rozpuštěné min. } \\
\text { látky (nad } \\
5 \mathrm{mg} / \mathrm{l}), \text { mohou } \\
\text { mít léč. účinky, } \\
\text { mohou } \\
\text { obsahovat - Fe, I, } \\
\text { Ba, As, } \\
\text { a probublávat } \\
\mathrm{H}_{2} \mathrm{~S}, \mathrm{CO}_{2}\end{array}$ & $\begin{array}{l}1 \text { les, ve kt. } \\
\text { převažuje buk lesní } \\
\text { a je častým lesem } \\
\text { v ČR, v případě ML } \\
\text { zde rostla bohatá } \\
\text { květena - způsobeno } \\
\text { ultrabazickými ionty } \\
\text { (konkr. hornina } \\
\text { rohovec) }\end{array}$ \\
\hline $\mathrm{H}$ & $\begin{array}{l}1 \text { vzniká za nepřístupu } \\
\text { vzduchu rozkladem } \\
\text { rašeliníku, ložiska } \\
\text { rašeliny }\end{array}$ & $\begin{array}{l}1 \text { oblast, kde je } \\
\text { půda slaná - min. } \\
\text { prameny, za sucha } \\
\text { může být } \\
\text { i vykrystalizovaná, } \\
\text { halofilní rostliny }\end{array}$ & $\begin{array}{l}1 \text { využívá léč. min. } \\
\text { pramenů, rekreace } \\
\text { a rehabilitace lidí }\end{array}$ & $\begin{array}{l}2 \text { vody s vyšším } \\
\text { obsahem minerálů, } \\
\text { max. } 2000 \mathrm{mg} / 1, \\
\text { zdraví prospěšná }\end{array}$ & $\begin{array}{l}1 \text { místo, kde je velké } \\
\text { množ. buků, } \\
\text { většinou tam není } \\
\text { moc kvetoucích } \\
\text { rostlin, Mar. Lázně - } \\
\text { výjimka kvůli jiným } \\
\text { horninám } \\
\end{array}$ \\
\hline $\mathrm{I}$ & $\begin{array}{l}2 \text { vznik ve třetihorách, } \\
\text { proces trvá do dnes, } \\
\text { roste zde rašeliník - } \\
\text { nikdy neodumře, je ho } \\
\text { spousta, část odumře, } \\
\text { ale v horní části opět } \\
\text { doroste }\end{array}$ & $\begin{array}{l}\text { oblast s častým } \\
\text { výskytem } \\
\text { jedinečných } \\
\text { a původních rostlin, } \\
\text { zmenšené formy } \\
\text { rost- } \\
\text { lin= přizpůsobení } \\
\text { prostředí, endemity } \\
\text { (ročec), vzácné }\end{array}$ & $\begin{array}{l}2 \text { léčitelství } \\
\text { využívá se zde } \\
\text { hlavně léčivých } \\
\text { a minerálních } \\
\text { pramenů a také } \\
\text { léčivých výparú } \\
\text { plynů (napŕ. síry) } \\
\text { z rašeliništ' }\end{array}$ & $\begin{array}{l}1 \text { vody s vyšším } \\
\text { obsahem min. } \\
\text { látek - } \\
50-200 \mathrm{mg} / 1, \\
\text { některé jsou } \\
\text { využívány k léčení }\end{array}$ & $\begin{array}{l}2 \text { bukový les, často } \\
\text { bez podrostu, bučina } \\
\text { u Františkových L. - } \\
\text { bohatá půda na } \\
\text { bazifyty - bohatý } \\
\text { lesní podrost }\end{array}$ \\
\hline $\bar{J}$ & $\begin{array}{l}1 \text { místo, podložím je } \\
\text { z převážné části } \\
\text { rašelina }\end{array}$ & $\begin{array}{l}1 \text { místo, kde je } \\
\text { v půdě hodně soli }\end{array}$ & $\begin{array}{l}\text { 1 obor, který se } \\
\text { zabývá léčením } \\
\text { chorob pomocí } \\
\text { pramenů nebo } \\
\text { jiného př́rodního } \\
\text { materiálu, který se } \\
\text { vyskytuje }\end{array}$ & $\begin{array}{l}2 \text { voda obohacená } \\
\text { o minerály }\end{array}$ & $\begin{array}{l}1 \text { "les", kde } \\
\text { převažuje buk }\end{array}$ \\
\hline
\end{tabular}




\begin{tabular}{|c|c|c|c|c|}
\hline $\begin{array}{l}\text { K } 1 \text { Oblast, jejímž } \\
\text { př́rodním základem je } \\
\text { rašelina či materiály jí } \\
\text { podobné }\end{array}$ & $\begin{array}{l}1 \text { oblast se slanými } \\
\text { půdami }\end{array}$ & $\begin{array}{l}1 \text { oblast medicíny } \\
\text { léčící pomocí } \\
\text { minerálních vod } \\
\text { a jiných přírodních } \\
\text { materiálů } \\
\text { souvisejících } \\
\text { s minerálními } \\
\text { vodami a rašelinou }\end{array}$ & 2 vody obohacené & $\begin{array}{l}1 \text { oblast } \mathrm{s} \text { bukovým } \\
\text { porostem }\end{array}$ \\
\hline
\end{tabular}

(nachází se na Křǐžkách), a nevyskytují se (vyjma ukázky v Geologickém parku) na Žižkově vrchu, který je budován bazickými horninami se snazším uvolňováním živin. Celkem sedm žáků odpovědělo zcela správně (oproti osmi před exkurzí), tři odpověděli nepřesně a jeden chybně, došlo tedy v celkovém skóre k mírnému zhoršení.

\subsection{Zastrukturování pojmů pomocí konceptových map před a po exkurzi}

Z celkových konceptových map před exkurzí vyplývají následující zjištění:

\section{Počet konceptů a hlavní koncept}

Sedm žáků před exkurzí nejčastěji rozpracovávali koncept lázeňství a čtyři rašeliniště a tři žáci minerální prameny (tab. 3). Celkem se pouštěli do podrobnějšího rozpracování 3-5 konceptů, ale často pouze spojili jednotlivé pojmy mezi sebou s minimálním doplněním dalších pojmů.

Tab. 3: Práce žáků s konceptovými mapami před exkurzí

Legenda: A-K - konceptové mapy jednotlivých žáků, hlavní koncept - nejvíce rozvinutý koncept (tedy takový pojem, který je propojen s nejvíce dalšími pojmy) je vyznačen kurzívně, nekurzívně jsou uvedeny i další rozvíjené koncepty

\begin{tabular}{|c|c|c|c|c|c|c|c|c|c|}
\hline \multirow[b]{2}{*}{ 菉 } & \multirow[b]{2}{*}{ 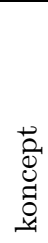 } & \multicolumn{2}{|c|}{ propojení } & \multirow[t]{2}{*}{ úroveň } & \multicolumn{2}{|c|}{$\begin{array}{c}\text { kř́̌žová } \\
\text { propojení }\end{array}$} & \multirow[t]{2}{*}{ Miskoncept } & \multirow[t]{2}{*}{ hlavní koncept } & \multirow{2}{*}{ 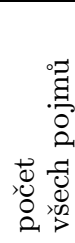 } \\
\hline & & 尝 & 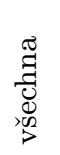 & & 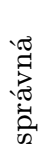 & 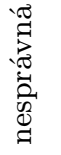 & & & \\
\hline$\overline{\mathrm{A}}$ & 4 & 7 & 7 & 1 & 0 & 0 & 0 & lázeňství & 7 \\
\hline$\underline{\mathrm{B}}$ & 4 & 8 & 8 & 1 & 0 & 0 & 0 & minerální vody, lázeňství & 19 \\
\hline$\overline{\mathrm{C}}$ & 5 & 16 & 17 & 2 & 3 & 1 & $\begin{array}{l}\text { komáři - minerální vody } \\
\text { (komáři př́liš nejsou } \\
\text { v minerálních vodách) }\end{array}$ & $\begin{array}{l}\text { rašeliniště, lázeňství, } \\
\text { minerální vody }\end{array}$ & 15 \\
\hline$\overline{\mathrm{D}}$ & 5 & 30 & 30 & 3 & 0 & 0 & 0 & $\begin{array}{l}\text { rašeliniště, slanisko, } \\
\text { lázeňství, minerální vody, } \\
\text { bučina }\end{array}$ & 38 \\
\hline$\overline{\mathrm{E}}$ & 5 & 8 & 8 & 2 & 8 & 0 & 0 & lázeñství & 9 \\
\hline$\overline{\mathrm{F}}$ & 5 & 24 & 24 & 2 & 4 & 0 & rašeliniště - slanisko & $\begin{array}{l}\text { rašeliniště, slanisko, } \\
\text { lázeňství, minerální vody, } \\
\text { bučina }\end{array}$ & 30 \\
\hline$\overline{\mathrm{G}}$ & 5 & 27 & 27 & 3 & 1 & 0 & 0 & $\begin{array}{l}\text { rašeliniště, lázeňství, } \\
\text { minerální vody }\end{array}$ & 27 \\
\hline$\underline{\mathrm{H}}$ & 4 & 4 & 4 & 1 & 0 & 0 & 0 & lázeňství, rašeliniště & 7 \\
\hline$\overline{\mathrm{I}}$ & 4 & 13 & 15 & 3 & 1 & 2 & $\begin{array}{l}\text { rašeliniště můžeme najít ve } \\
\text { vyvýšených oblastech nebo } \\
\text { mezi slanisky }\end{array}$ & minerální prameny & 16 \\
\hline$\overline{\mathrm{J}}$ & 5 & 5 & 5 & 1 & 0 & 0 & 0 & $\begin{array}{l}\text { rašeliniště, slanisko, } \\
\text { lázeñství, minerálni vody, } \\
\text { bučina }\end{array}$ & 8 \\
\hline$\overline{\mathrm{K}}$ & 3 & 28 & 28 & 4 & 0 & 0 & 0 & minerální vody & 34 \\
\hline
\end{tabular}

\section{Počet všech pojmů před exkurzí}

Celkový počet pojmů užitých žáky před jejím absolvováním exkurze se pohybuje v rozmezí od 7 do 38 , průměrně 19 pojmů (viz tab. 3), přičemž 5 pojmů bylo předem daných (rašeliniště, lázeňství, minerální prameny, bučina, slanisko). 


\section{Správná a nesprávná propojení mezi pojmy, miskoncepty}

Celkový počet propojení mezi pojmy se před exkurzí pohyboval v rozmezí od 4 do 30 , průměrně 15 propojení. Z toho došlo ke dvěma nesprávným propojením, např. komáři a minerální vody (komáři nevyhledávají minerální vody) a rašeliniště a vyvýšené oblasti a mezi slanisky (rašeliniště nejsou pouze na vyvýšených místech) a se slanisky jsou kontraktována výjimečně, např. v NPR Soos.

\section{Kř̌žzová propojení}

Před exkurzí šest žáků vůbec nepouživá propojení mezi jednotlivými koncepty. Pět žáků používá 1 a 8 kř́ižových propojení, průměrně 1,5 . Z toho jsou 3 propojení nesprávná (komáři a minerální vody, rašeliniště a můžeme je najít ve vyvýšených oblastech nebo mezi slanisky).

\section{Počet úrovní}

Žáci před exkurzí zastrukturovávali pojmy do 1 až 4 úrovní (tab. 3).

Z celkových konceptových map po exkurzi vyplývají následující zjištění:

\section{Počet konceptů a hlavní koncept}

Po exkurzi se počet konceptů zvýšil na celkem 4-6 konceptů (viz tab. 4), u šesti žáků přibyl další koncept. Pouze u jednoho žáka se počet rozpracovávaných konceptů o jeden snížil. Po absolvování exkurze je nejčastěji rozpracován jako hlavní koncept minerální vody (5 žáků). Dále rašeliniště (4 žáci), a pak shodně tři žáci rozpracovávají lázeňství a bučinu. Žádný žák nerozpracovává jako hlavní koncept slanisko (možná i proto, že se jedná o pojem, se kterým se dosud prŕliš nesetkali).

Tab. 4: Práce žáků s konceptovými mapami po exkurzi

Legenda: A-K - konceptové mapy jednotlivých žáků po exkurzi, hlavní koncept (nejvíce rozvinutý koncept je vyznačen kurzívně), nekurzívně jsou uvedeny i další rozvíjené koncepty

\begin{tabular}{|c|c|c|c|c|c|c|c|c|c|c|c|}
\hline \multirow[b]{2}{*}{ 菏 } & \multirow[b]{2}{*}{ 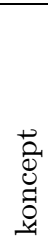 } & \multicolumn{2}{|c|}{ propojení } & \multicolumn{3}{|c|}{$\begin{array}{c}\text { křrižová } \\
\text { propojení }\end{array}$} & \multirow[t]{2}{*}{ Miskoncept } & \multirow[t]{2}{*}{ hlavní koncept } & \multirow{2}{*}{ 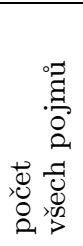 } & \multirow[b]{2}{*}{ 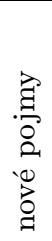 } & \multirow{2}{*}{ 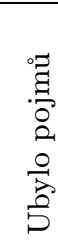 } \\
\hline & & 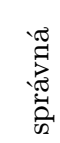 & 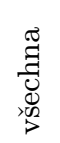 & 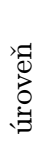 & 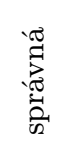 & 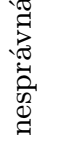 & & & & & \\
\hline$\overline{\mathrm{A}}$ & 5 & 10 & 10 & 2 & 1 & 0 & 0 & lázeňství & 11 & 3 & $\overline{1}$ \\
\hline$\overline{\mathrm{B}}$ & 4 & 15 & 15 & 2 & 2 & 0 & 0 & mineralni vody, rašeliniště & 19 & 9 & $\overline{2}$ \\
\hline$\overline{\mathrm{C}}$ & 5 & 4 & 4 & 1 & 0 & 2 & $\begin{array}{l}\text { rašeliniště tvoří kyselá } \\
\text { půda, minerální voda tvoří } \\
\text { slanisko }\end{array}$ & mineralní vody & 6 & 2 & $\overline{9}$ \\
\hline$\overline{\mathrm{D}}$ & 5 & 38 & 38 & 3 & 0 & 3 & $\begin{array}{l}\text { vyvýšená rašeliniště } \\
\text { (namísto vrchoviště), } \\
\text { bahenní sopky (namísto } \\
\text { mofety), mufáty }\end{array}$ & $\begin{array}{l}\text { rašeliniště, slanisko, } \\
\text { lázeňství, minerální vody, } \\
\text { bučina }\end{array}$ & 43 & 7 & $\overline{10}$ \\
\hline$\overline{\mathrm{E}}$ & 4 & 6 & 6 & 1 & 0 & 0 & 0 & lázeňství & 7 & 0 & $\overline{3}$ \\
\hline$\overline{\mathrm{F}}$ & 5 & 29 & 29 & 2 & 1 & 1 & $\begin{array}{l}\text { rašeliniště propojené se } \\
\text { slaniskem }\end{array}$ & $\begin{array}{l}\text { bučina, minerální vody, } \\
\text { rašeliniště }\end{array}$ & 36 & 17 & $\overline{3}$ \\
\hline$\overline{\mathrm{G}}$ & 5 & 74 & 74 & 5 & 6 & 1 & $\begin{array}{l}\text { prohozené suchopýry u typů } \\
\text { rašeliništ }\end{array}$ & bučina & 75 & 57 & $\overline{2}$ \\
\hline$\overline{\mathrm{H}}$ & 4 & 10 & 10 & 2 & 0 & 1 & $\begin{array}{l}\text { rašeliniště - jen málo } \\
\text { živočichů }\end{array}$ & lázeňství & 11 & 5 & $\overline{1}$ \\
\hline$\overline{\mathrm{I}}$ & 5 & 0 & 0 & 3 & 4 & 2 & $\begin{array}{l}\text { skalisko (místo slanisko) - } \\
\text { bučina, bahenní (suché) } \\
\text { sopky }\end{array}$ & rašelinistě & 24 & 4 & $\overline{3}$ \\
\hline $\bar{J}$ & 6 & 14 & 14 & 3 & 2 & 0 & 0 & minerální vody & 11 & 3 & \\
\hline$\overline{\mathrm{K}}$ & 4 & 70 & 69 & 4 & 0 & 2 & $\begin{array}{l}\text { minerální vody - mofety, } \\
\text { acidofyty - čedič }\end{array}$ & minerální vody & 47 & 23 & \\
\hline
\end{tabular}

\section{Počet všech pojmů po exkurzi a počet nových pojmů po exkurzi}

Po absolvování exkurze se počet pojmů zvýšil, pohyboval mezi 7 a 75 pojmy, průměrně 27 pojmů (tab. 4). U většiny žáků počet pojmů po exkurzi vzrostl, pouze u dvou se snížil (z 19 na 9 a z 9 na 7 ). Počet nových pojmů v konceptové mapě po exkurzi, které nebyly v konceptové mapě před exkurzí, se pohyboval od 3 do 57, u třech žáků se neobjevil žádný nový pojem, průměrný nárůst nových pojmů je 11. Po exkurzi se 
v pojmových mapách objevila řada pojmů, které se žáci dozvěděli během exkurze, ale naopak zmizely i správné pojmy, které byly v pojmových mapách před exkurzí.

\section{Správná a nesprávná propojení mezi pojmy, miskoncepty}

Po absolvování exkurze se počet propojení pohyboval mezi 4 a 74 , průměrně 24 propojení. Objevují se zde i nevhodná propojení, např. rašeliniště tvoří kyselá půda a minerální voda tvoří slaniska, což takto nelze propojit. Chybně je propojeno rašeliniště a jen málo živočichů, což nemusí být pravda. V jedné konceptové mapě jsou minerální vody spojovány s mofetami. Chybně jsou propojovány acidofyty a čedič, s čedičem by měli být propojeny bazifyty.

Kromě sedmi chybných propojení se zde objevují i tři nové miskoncepty, jako např. vyvýšená rašeliniště místo vrchoviště, bahenní sopky, bahenní (suché) sopky či mufáty namísto mofety, což jsou na rozdíl od bahenních sopek suché výrony $\mathrm{CO}_{2}$ a $\mathrm{H}_{2} \mathrm{~S}$. Dále je jako dominantní na vrchovišti uváděn suchopýr úzkolistý a jako převládající na místech s větší dotací vody suchopýr pochvatý, což je naopak. Je zaměňován pojem skalisko a slanisko. Po exkurzi se počet miskonceptů i počet chybných propojení zvýšil (cf. obr. 3,4). Miskoncepty, které se objevovaly před exkurzí, už se neobjevují, pouze v jednom př́́padě propojení rašeliniště se slaniskem, ale u jiného účastníka než před exkurzí.

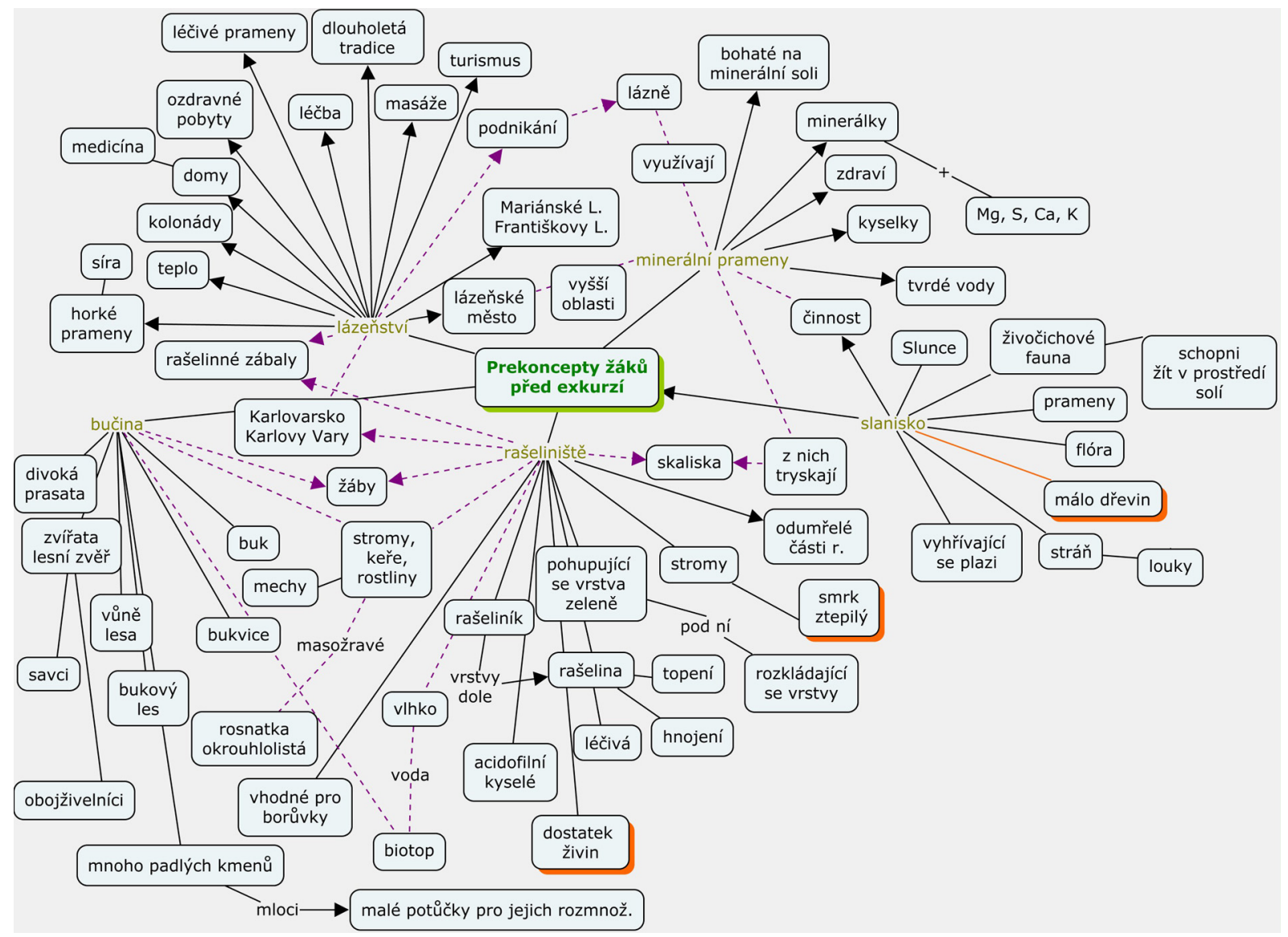

Obr. 3: Souhrnná konceptová mapa před exkurzí; oranžově jsou podbarveny miskoncepty, zelenohnědě hlavní koncepty a fialově kř́ǐzová propojení (vytvořeno v programu CMapTools; http://cmap.ihmx.us)

\section{Kř́žová propojení}

Po exkurzi 6 žáků použilo kř́žzvá propojení, počet kř́ižových propojení se pohybuje mezi 1 a 5 , průměrně 1,3. V jednom případě se vyskytlo chybné křížové propojení (rašeliniště a slanisko. Zastrukturování pojmů je evidentně pro žáky velmi obtížné, a navíc nedochází k propojení mezi prekoncepty a novými pojmy.

\section{Počet úrovní}

Žáci po exkurzi zastrukturovávali pojmy do 1 a 5 úrovní. Průměrný počet použitých úrovní se po exkurzi zvýšil ze 2 na 2,5 . 
Porovnání celkové konceptové mapy vytvořené ze všech konceptových map žáků exkurze před a po exkurzi ukazuje zvýšení počtu použitých pojmů. Nejvíce pojmů přibylo u konceptu minerální prameny, naopak koncept lázeňství je téměř shodně propracován jako před exkurzí.

V celkové konceptové mapě před exkurzí (obr. 3) byly pouze 3 zásadní miskoncepty, rašeliniště a dostatek živin (ve skutečnosti je rašeliniště oligotrofní až dystrofní stanoviště) a stromy na rašeliništi a smrk ztepilý (typické pro rašeliniště, která byla navštívena, jsou borovice, hlavně borovice blatka - Pinus rotundata). Před exkurzí bylo zaznamenáno i chybné propojení mezi slaniskem a málo dřevin, na navštívených slaniscích byly pouze náletové dřeviny, ale dřeviny typické pro slaniska se zde vůbec nevyskytovaly.

Po exkurzi přibylo 37 názvů druhů rostlin u jednotlivých ekosystémů rašeliniště, bučina, slanisko (obr. 4).

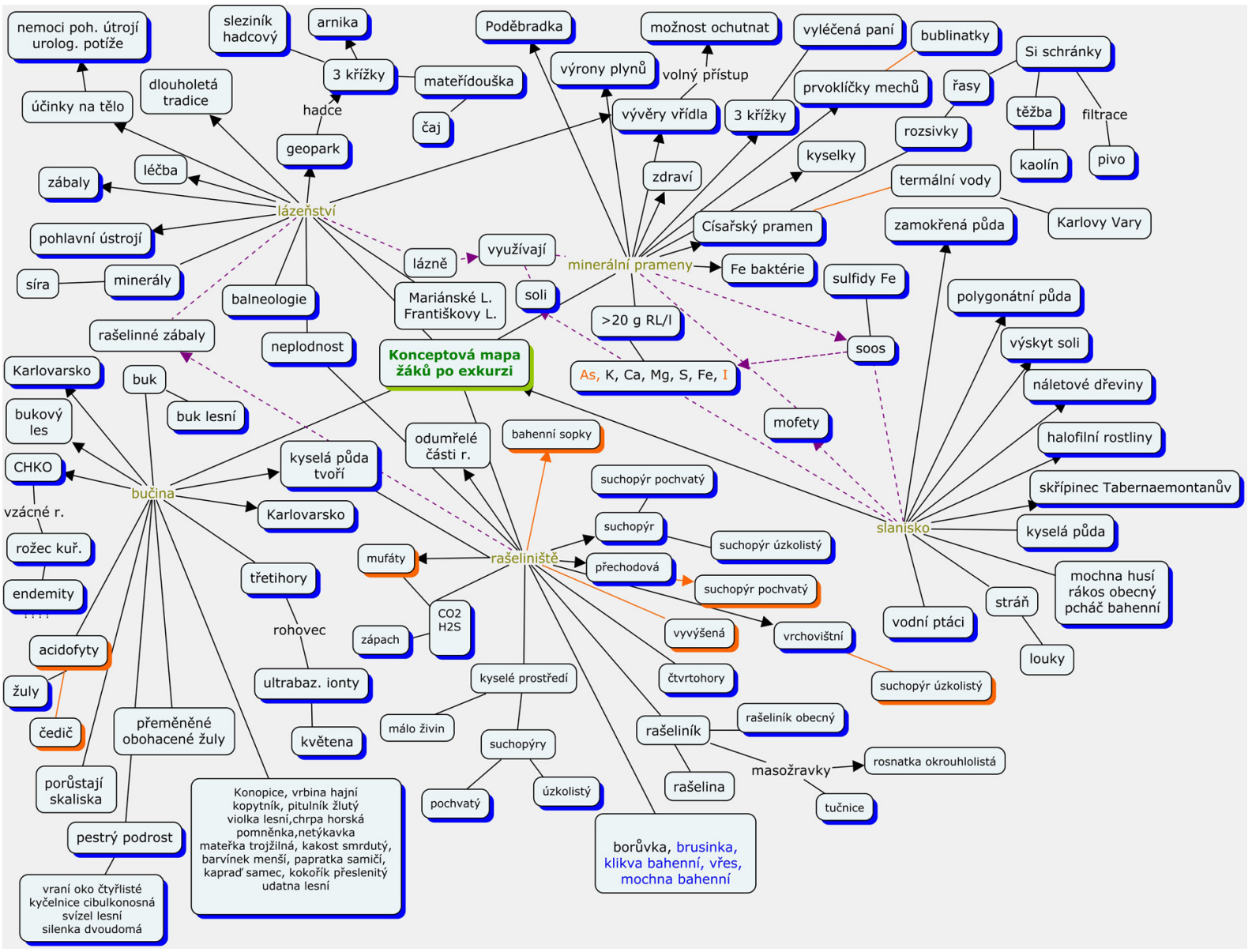

Obr. 4: Souhrnná konceptová mapa po exkurzi; oranžově jsou podbarveny miskoncepty, zelenohnědě hlavní koncepty a fialově křížová propojení (vytvořeno v programu CMapTools; http://cmap.ihmx.us)

Po exkurzi se počet miskonceptů ${ }^{7}$ zvýšil na pět, problém dělaly žákům hlavně mofety a bahenní sopky jako nové pojmy, které byly vysvětlovány a rovněž zastrukturování bylo obtížné ( 7 chybných propojení, např. prvokličky mechů a bublinatky - nemají spolu nic společného, Císařský pramen a termální vody, opět Císařský pramen nesplňuje předpoklady termální vody). Po exkurzi se žáci více pokoušeli propojovat jednotlivé koncepty, i když velmi jednoduchým způsobem. Přestože se nezvýšil celkový počet úrovní, do kterých žáci zastrukturovali pojmy, zásadně se zvýšila frekvence použití víceúrovňového zastrukturování pojmů.

Jak již bylo uvedeno, v konceptové mapě po exkurzi je řada nových pojmů i nových propojení, ale zjevně nedošlo k propojení prekonceptů a nově nabytých pojmů, jen výjimečně dochází k jejich zastrukturování. Zároveň se však některé pojmy po exkurzi v konceptových mapách neobjevily. Jednalo se o 1-10 pojmů: biotop, medicína, domy, nebezpečí, rostliny, žáby, mechy, voda, léčba, turismus, teplo, minerály, vrstvy, mokřady, plazi, podnikání, Mariánské Lázně, Františkovy Lázně, zdraví, kmeny, savci, obojživelníci, fauna, flóra, biotop, kolonády, železité prameny, divoká prasata, lesní zvěř, masáže, rašelinné zábaly, acidofilní půda, vřes, smrk ztepilý, vyvěrají a zdraví (viz tab. 4). Chybí také jednoduchá

\footnotetext{
${ }^{7}$ Miskoncepce může vzniknout nejenom tak, že žák přiřazuje prezentovaným slovům či znakům chybnou představu, ale také tehdy, když k nim není schopen přiřadit představu žádnou (Hejný, et al., 1989, s. 29, cit. podle Mareš \& Ouhrabka, 1992, s. 86).
} 
propojení, která žáci jistě znají, např. žáby - obojživelníci - zvířata, rostliny - borůvky, divoká prasata zviřata - savci. Obtížnější propojení, které se neobjevilo v konceptové mapě po exkurzi, např. halofilní rostliny a skř́ípinec Tabernaemontanův.

Porovnáním pojmů byla zjištěna $31 \%$ shoda mezi konceptovou mapou před a po exkurzi (CmapTools).

\subsection{Vizualizace souhrnu konceptových map před a po exkurzi (pomocí Gephi)}

Na první pohled je patrné, že po exkurzi je konceptová mapa daleko bohatší, což je vyjádřeno zvýšeným počtem uzlů a hran (obr. 5,6 ). Po exkurzi žáci rovněž více vypisovali názvy rostlin, pramenů, měst apod. Před exkurzí hlavními koncepty (pojmy) byly: rašeliniště, lázeňství, minerální prameny, bučina, slaniska. Po exkurzi to byly pojmy rašeliniště, minerální vody, bučina, slaniska, lázeňství. Tyto hlavní pojmy se po exkurzi nezměnily, ale jejich počet byl po exkurzi relativně menší, zatímco celá sít pojmů se zvětšila, tj. obohatila se struktura prekonceptů, jak je má k dispozici „společenství myslí “ v této skupině žáků (počet vzájemně navazujících slov). Lze proto přepokládat, že dialog v takto „obohacené“ skupině žáků by byl obohacený v terminologii i na úrovni vědomí souvislostí mezi pojmy.

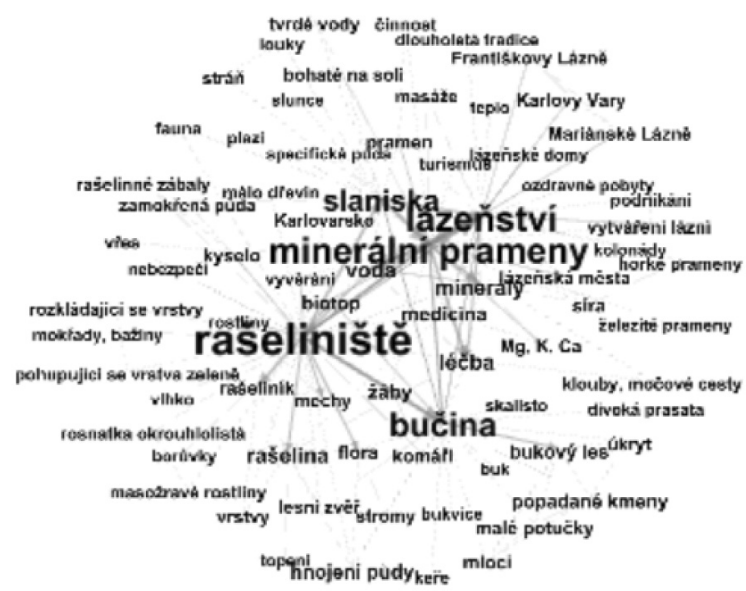

Obr. 5: Vizualizace konceptových map před exkurzí (pomocí softwaru Gephi); počty: uzly (slova): 75, hrany (spojení): 177

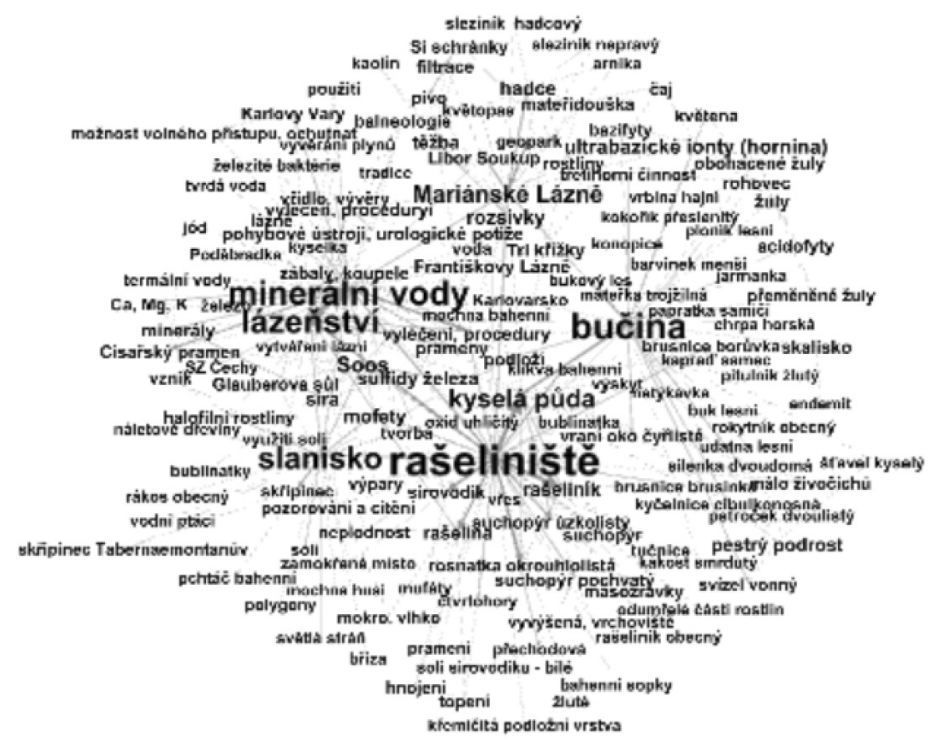

Obr. 6: Vizualizace konceptových map po exkurzi (pomocí softwaru Gephi); počty: uzly (slova): 145, hrany (spojení): 322 


\section{Diskuse}

Škola je často kritizována za to, že si vystačí s reprodukováním učiva, nezabývá se příliš tím, jak žák učivu porozuměl, co si pod odř́́kávaným učivem představuje, jak o něm uvažuje. V zásadě se tím kritizuje, že žáci nepoužívají přemýšlení a komunikace „do hloubky“, tj. opřené o logiku a významové vazby mezi pojmy. Abychom se mohli touto kritikou začít věcně zabývat, potřebujeme nástroj a metodiku pro zkoumání sémantických a logických vazeb ve struktuře žákovských prekonceptů. Z analýzy literatury uvedené výše v oddíle 4.3 Metoda konceptového mapování vyplývá, že př́hodným nástrojem pro tento typ zkoumání jsou konceptové mapy.

V tomto sdělení informujeme o využití metodiky založené na konceptovém mapování kognitivní struktury prekonceptu. Výzkum založený na uplatnění konceptových map realizovali u nás počátkem milénia Doulík a Škoda (2003, s. 181-182) ve školním prostředí. Jejich přístup byl postaven na kvantitativní a kvalitativní vyhodnocení žákovské odezvy na několik fixních „zastrukturovacích schémat“. Ta byla podkladem pro komparace mezi žáky a pro zpracování hromadných údajů.

Náš výzkum na rozdíl od toho ponechal žákům volnost při tvorbě konceptové mapy, takže kvalitativní změny struktury v prekonceptu (tj. změny „míry zastrukturováni““) jsme mohli sledovat bezprostředněji ve vztahu k tvorbě mapy. Náš výzkum měl však mnohem užší časový rozsah než citovaný výzkum Doulíka a Škody (2003), kteří sledovali vývoj v intervalu 3.-9. ročníku základní školy. Naší výhodou ale je, že díky velmi krátkému časovému intervalu můžeme modifikaci prekonceptů jednoznačněji připsat vzdělávacímu vlivu výuky (nemusíme se zabývat jinými možnými vlivy mimo výuku). Shodně s citovanými autory jsme zjistili pozitivní změny ve struktuře prekonceptů způsobené výukou.

V mimoškolním prostředí, v rámci př́rodovědné exkurze, byla při využití konceptových map ve výzkumech věnována pozornost především kognitivní oblasti žákova chápání obsahu jednotlivých pojmů, žákova chápání vztahů mezi nimi. Porovnání pojmových map před a po exkurzi v různých výzkumech ukázalo na rozšiř̌ení pojmového aparátu zúčastněných žáků. Pozitivní vliv terénních exkurzí na přírodovědné znalosti a porozumění vzájemným vztahům v př́rodě zdůrazňují ve své studii např. Erdogan, Usak a Bahar (2013). Současně s tím uvádějí, že vliv na postoje je zanedbatelný.

V naší studii jsme se s tímto výzkumem shodli v pozitivním vlivu terénní exkurze na rozvoj př́rodovědných znalostí a porozumění vzájemným vztahům v př́rodě. Nevěnovali jsme se však vlivu na postoje žáků k přírodě. Jak jsme vysvětlili výše, náš vzorek žáků byl charakterizován zvýšenou motivací v tomto směru a nepovažovali jsme za potřebné se jejich postojům detailněji věnovat.

Erdogan (2015) uvádí v různých svých studiích protichůdné závěry o mîře a kvalitě vlivu výuky. V roce 2015 zjistil pozitivní efekt přírodovědné exkurze na posílení environmentálních znalostí a postojů u žáků, ale ve své dř́vějš̌́ studii z roku 2011 hodnotil dopad na znalosti a postoje jako nevýznamný. Pozitivní vliv terénní výuky na žákovské znalosti potvrzují z nedávné doby Činčera a Holec (2016).

Národní rada pro výzkum USA (2009, s. 130 a 132) zdůraznila důležitou roli exkurzí a akcentovala rovněž dlouhodobý dopad exkurzí na změny postojů žáků k přírodě a přírodním jevům, což zmiňují i další autoři (Anderson et al., 2003; Storkdieck, 2006; Greene et al., 2014). Podle práce Andersona a Zhanga (2003) $90 \%$ učitelů považuje terénní exkurze za velmi hodnotný výukový prostředek s motivujícím efektem.

Z našich výsledků je zřejmé, že motivovaní žáci druhého stupně ZŠ a gymnázií jsou během exkurze schopni si zapamatovat relativně velké množství pojmů na různých úrovních, od obecných pojmů (např. geopark) až po názvy jednotlivých druhů rostlin (např. arnika, sleziník hadcový), ale mají problémy $\mathrm{s}$ jejich zastrukturováním. Projevuje se to ve faktu, že ve svých konceptových mapách téměř nepoužívají propojovací slova, přestože při vysvětlování principu tvoření konceptové mapy na př́kladu „rodiny“ všichni tohoto propojení byli schopni.

Jsme si vědomi toho, že hodnocení reálného vzdělávacího př́nosu terénní výuky pro kvalitu modifikace prekonceptů žáků je jistě možné až s určitým časovým odstupem. Jak výstižně formulovali Mareš a Ouhrabka (1992, s. 86):

Do hry vstupuje jak učitel (nakolik se k učivu vrací, jak jej obohacuje o nové souvislosti) i žák (jak probíhá zapomínání jednotlivých prvků učiva, nakolik se modifikuje celá sít vztahů mezi prvky učiva, jaké zkušenosti získává při práci s navazujícím učivem, v jakých situacích s učivem pracuje, nakolik pokládá dané učivo za důležité pro budoucnost atp.).

Naše sdělení si však nekladlo za cíl potvrzovat nebo obhajovat celkový vzdělávací př́ínos exkurze, ale bylo mnohem skromněji zaměřeno na vyhodnocení jen několika aspektů takového př́nosu v oblasti kognitivní struktury prekonceptu. Naším záměrem bylo získat konkrétní podklady pro náhled na to, jak se pod vlivem výuky může modifikovat struktura žákovských prekonceptů a na jaké problémy či překážky přitom mohou žáci narážet. Vzhledem $\mathrm{k}$ tomu, že jsme pro své zkoumání zvolili skupinu žáků, kteři se zajímají o biologii či přírodní vědy, lze předpokládat, že zjištěné problémy či překážky by v prŕpadě 
náhodně vybraného vzorku byly zřetelnější, zatímco přínosy exkurze ve sledovaných aspektech u méně motivovaných žáků by mohly být slabší.

V metodologické oblasti jsme v našem sdělení usilovali o návaznost teoretického pojetí prekonceptu na zkoumání kognitivních modifikací prekonceptu pod vlivem výuky. Opřeli jsme se nejprve o myšlenku tzv. „zastrukturování“ prekonceptu v analogii k strukturnímu pojetí pojmu (Materna, 1995, 1997; Doulík \& Škoda, 2003; Slavík et al., 2017; Kohout et al., 2019).

Na tomto podkladě jsme dospěli k teorii konceptuální změny jako k výkladovému rámci, který dovoluje vysvětlovat modifikaci prekonceptu jako proces směřující ke konceptuální změně. Jestliže je modifikace žákovského prekonceptu zacílena na porozumění oborům, specifikujeme ji termínem instrumentalizace žákovy zkušenosti, protože vede žáka k zvládání poznávacích a komunikačních instrumentů oboru.

Teorie konceptuální změny je mimo jiné př́hodná tím, že ji lze uplatnit nejenom s ohledem na jednotlivé žáky, ale i v širších souvislostech společenství („společenství myslí“; srov. Slavík et al., 2017, s. 45-47), např. ve školní třídě nebo dokonce při historickém vývoji poznávání v oborech (srov. Posner et al., 1982).

Teorie konceptuální změny klade důraz na komplexní strukturní pojetí konceptů, resp. prekonceptů. Proto ke konkrétnímu zkoumání modifikací prekonceptů ve výuce vyžaduje takový nástroj, který umožňuje bezprostředně zachytit „zastrukturování“ prekonceptu. Tímto nástrojem jsou konceptové mapy.

\section{Závěr}

Konceptové mapy byly využity v našem výzkumu modifikace prekonceptů způsobené vzdělávacím vlivem terénní biologické exkurze. Tímto výzkumem ale můžeme přispět k ověřování možností využití konceptových map pro výzkumy modifikací žákovských prekonceptů pod vlivem jakékoliv výuky, nikoliv jen terénní exkurze. Cíl exkurze byl splněn, u žáků došlo k propojení teoretických poznatků ze školního prostředí s realitou $\mathrm{v}$ terénu.

Naším výzkumem byla ve shodě se zjištěním jiných autorů (viz výše v kapitole 5.2 a 5.3 ) potvrzena dobrá využitelnost konceptových map pro daný účel. Potenciál užití konceptových map spatřujeme nejenom pro výzkum v tom zaměření a rozsahu, který jsme realizovali, ale i pro jeho případná doplnění dalšími výzkumnými postupy (rozhovor, dotazník, ohnisková skupina apod.) nebo pro jeho pokračování ve výuce formou akčního výzkumu spolu s učiteli.

Výsledky výzkumu přinesly odpovědi na výzkumné otázky a naplnily cíl výzkumu. Na základě diagnostiky vstupních prekonceptů žáků/účastníků na počátku exkurze ve srovnání s modifikovanými prekoncepty týchž žáků v závěru exkurze bylo zjištěno, že po exkurzi došlo k obohacení konceptových map žáků novými uzly (pojmy) i jejich vztahy (hranami). Došlo též k jasnější a přesnější konkretizaci konceptů na základě proběhlé exkurze a v kontextu vybrané lokality, což lze hodnotit pozitivně jako př́spěvek k lepšímu obsahovému zvládání pojmu.

Výzkum ukázal též jeden důležitý didaktický problém, který se projevil sníženou kvalitou zastrukturování konceptových map, tj. v kvalitách provázanosti mezi pojmy v ní. Lze hypoteticky odhadovat, že důvodem může být školní výuka biologie, která je často zaměřena na memorování velkého množství odborných pojmů, a žákům unikají jejich logické vazby, které se často dostaví až s časovým odstupem. Pro analýzu platnosti této hypotézy a zjištění příčin tohoto problému by bylo nutné v budoucnu sledovat vývoj poznatků žáků s větším časovým odstupem.

Pro školní praxi lze doporučit, že by se žáci měli více učit v terénu, aby pro ně analýza a implementace školních poznatků do prrírodního prostředí nebyla tak obtížná a výuka biologie a přírodopisu nebyla odtržena od každodenního života a přírody. Jak uvádí Klimešová (2015, s. 1):

Biologie je plná seznamů, které se dají učit nazpamět, a část žáků a určitě i někteří učitelé vidí právě memorování jako cestu k pochopení předmětu (vyjmenovat všechny taxonomické skupiny a u každé tři zástupce apod.). Obor však zahrnuje také spoustu příběhů a mechanismů, na které bychom neměli zapomínat.

\section{Poděkování}

Publikace vznikla díky podpoře dotačního programu MŠMT Podpora nadaných žáků základních a středních škol v roce 2018 s názvem „Aktivity podporující přírodovědné vzdělávání nadaných žáků v Plzeňském a Karlovarském kraji II" (0060/7/NAD/2018).

Autorky děkují recenzentům za cenné připomínky k rukopisu článku, děkují panu doc. PaedDr. Janu Slavíkovi, CSc., za konzultaci, která přispěla k projasnění vztahů teoretického výkladu k výsledkům šetření. Dále pak doc. Mgr. Aleně Nohavové, Ph.D., za technickou a metodickou podporu př̀i zpracování vizualizace dat v Gephi. 


\section{Literatura}

Anderson, D., \& Zhang, Z. (2003). Teacher perceptions of field-trip planning and implementation. Visitor Studies Today, 6(3), 6-11.

Anderson, D., \& Zhang, Z. (2003). Teacher perceptions of field-trip planning and implementation. Visitor Studies Today, 6(3), 6-11.

Bastian, M., Heymann, S., \& Jacomy, M. (2009). Gephi: An open source software and manipulating networks. In Proceedings of the Third Internacional ICWSM Conference. (pp. 361-362). https://www.aaai.org/ocs/index.php/ICWSM/09/paper/viewFile/154/1009

Behrendt, M., \& Franklin, T. (2014). A review of research on school field trips and their value in education. International Journal of Environmental and Science Education, 9(3), 235-245. https://doi.org/10.12973/ijese.2014.213a

Brady, E. R. (1972). The effectiveness of field trips compared to media in teaching selected environmental concepts [Retrospective Theses and Dissertations]. https://lib.dr.iastate.edu/rtd/5887

Bruun, J., \& Evans, R. (2018). Network analysis as a research methodology in science education Research. Pedagogika, 68(2), 201-217. https://doi.org/10.14712/23362189.2017.1026

Cimer, A. (2007). Effective teaching in science: A review of literature. Journal of Turkish Science Education, 4(1), 1-25. http://citeseerx.ist.psu.edu/viewdoc/download?doi=10.1.1.125.4441\&rep=rep1\&type=pdf

Clark, E. C. (1943). An experimental evaluation of the school excursion. Journal of Experimental Education, 12(1), 10-19.

Crawford, C. C., \& Grinstead, R.W. (1930). The use of the excursion in teaching commerical geography. The Journal of Geography, 29(7), 301-306.

Čáp, \& Mareš, (2001). Psychologie pro učitele. Praha: Portal. 656 s.

Capek, R. (2015). Moderní didaktika. Lexikon výukových a hodnoticích metod. Grada.

Činčera, J., \& Holec, J. (2016). Terénní výuka ve formálním vzdělávání. Envigogika, 11(2), 1-19. https://doi.org/10.14712/18023061.533

DeWitt, J., \& Storksdieck, M. (2008). A short review of school field trips: Key findings from the past and implications for the future. Visitor Studies, 11(2), 181-197. https://doi.org/10.1080/10645570802355562

Di Sessa, A. A. (2007). Changing conceptual change. Human Development, 50, 39-46.

Di Sessa, A. A. (2008). A bird'seye view of the "Pieces" vs "Coherence" controversy. In S. Vosniadou (Ed.), International handbook of research on conceptual change (pp. 35-60). Routledge.

Doulík, P. (2005). Geneze dětských pojetí vybraných fenoménů. Acta universitatis Purkynianae.

Doulík, P., \& Škoda, J. (2003). Tvorba a ověření nástrojů kvantitativní diagnostiky prekonceptů a možnosti jejího vyhodnocení. Pedagogika, 53(2), 117-189.

Dvořáková, M. (2013). Diagnostikování dětských pojetí společnosti studenty učitelství. Orbis Scholae, 7(1), 101-117. https://doi.org/10.14712/23363177.2015.28

Erdogan, M. (2015). The effect of summer environmental education program (SEEP) on elementary school students' environmental literacy. International Journal of Environmental and Science Education, 10(2), 165-181. https://doi.org/10.12973/ijese.2015.238a

Erdogan, M., Uşak, M., \& Bahar, M. (2013). A review of research on environmental educa-tion in non-traditional settings in Turkey, 2000 and 2011. International Journal of Environmental and Science Education, 8(1), 37-57.

Fraser, J. A. (1939). Outcomes of a study excursion, a descriptive study. Teachers College, Columbia University, Contributions to Education.

Glynn, S., \& Duit, R. (1995). Learning Science Meaningfully: Constructing Conceptual Models. In S. M. Glynn, \& R. Duit (Eds.), Learning science in the schools (pp. 1-33). Lawrence Erlbaum Associates.

Goodman, N., \& Elginová, Z. E. (2017). Nové pojetí filozofie a dalších umění a věd. Univerzita Karlova, Filozofická fakulta.

Gray, E. M., \& Tall, D. (1994). Duality, ambiguity, and flexibility: A proceptual view on simple arithmetic. Journal of Research on Mathematic Education, 25(2), 116-141. https://doi.org/10.2307/749505

Greene, J. P., Kisida, B., \& Bowen, D. H. (2014). The educational value of field trips. Education Next, 14(1), $78-86$.

Hejný, M. (2003). Diagnostika aritmetické struktury. In V. Burian, M. Hejný, \& Ś. Jány (Eds.), Zborník príspevkov z letnej školy z teórie vyučovania matematiky PYTHAGORAS 2003 (pp. 22-42). Exam. 
Hejný, M., Bero, P., Vantuch, J., Benešová, M., Bereková, H., Repáš, V., \& Hrdina, L. (1989). Teórie vyučovania matematiky. Bratislava: SPN.

Hejný, M., \& Kư̌ina, F. (2001). Dítě, škola a matematika. Portál.

Hendl, J. (2005). Kvalitativní výzkum. Základní metody a aplikace. Portál.

Hrouda, L., \& Chocholoušková, Z. (2013). Chráněné krajinné oblasti ČR a jejich botanický význam: př́ručka $k$ projektu Věda do škol. Univerzita Karlova v Praze, Pedagogická fakulta.

Chocholoušková, Z., \& Hajerová Müllerová, L. (2019). Didaktika biologie ve vztahu mezi obecnou a oborovou didaktikou. ZČU.

Chocholoušková, Z., \& Hrouda, L. (2013). Exkurze do vybraných území západních Čech: př́ručka k projektu Věda do škol. Univerzita Karlova, Pedagogická fakulta.

Iuli, R. J., \& Helldén, G. (2004). Using concept maps as a research tool in science education research. In Concept maps: theory, methodology, technology: Proceedings of the First International Conference on Concept Mapping (pp. 367-374). Servicio de Publicaciones de la Universidad Pública de Navarra. Pamplona, Spain.

Jacobs-Lawson, J. M., \& Hershey, D. A. (2002). Concept maps as an assessment tool in psychology courses. Methods, \&S Techniques, 29(1), 25-29. https://doi.org/10.1207/S15328023TOP2901_06

Janík, T. (2006). Teorie konceptuální změny a učebnice. In J. Maňák, \& D. Klapko (Eds.), Učebnice pod lupou (s. 33-44). Paido.

Janík, T., Slavík, J., Mužík, V., Trna, J., Janko, T., Lokajíčková, V., Lukavský, J., Minaříková, E., Sliacky, J., Šalamounová, Z., Šebestová, S., Vondrová, N., \& Zlatníček, P. (2013). Kvalita (ve) vzdělávání. Obsahově zaměřený přistup ke zkoumání a zlepšování výuky. Masarykova univerzita.

Killermann, W. (1998). Research into biology teaching methods. Journal of Biological Education, 33(1), 4-9. https://doi.org/10.1080/00219266.1998.9655628

Kisiel, J. (2005). Understanding elementary teachers motivations for science fieldtrips. Wiley Periodicals INc., 89(6), 936-955. https://doi.org/10.1002/sce.20085

Klieme, E., Pauli, Ch., \& Reusser, K. (2009). The Pythagoras study: Investigating effects of teaching and learning in Swiss and German mathematics classrooms. In T. Janík, \& T. Seidel (Eds.), The power of video studies in investigating teaching and learning in the classroom (pp. 137-160). Waxmann.

Klimešová, J. (2015). Měli bychom denně přemýšlet o tom, jak učit biologii. Živa, 4(2015), 1.

Kohout, J., Mollerová, M., Masopust, P., Feřt, L., \& Slavík, J. (2019). Kritická místa kurikula na základní škole pohledem mezinárodního šetření TIMSS a českých učitelů - poznatky z fyziky. Pedagogická orientace, 29(1), 5-42. https://doi.org/10.1063/1.5124767

Koncepce podpory rozvoje nadání a péče o nadané na období let 2014-2020. (2014).

http://www.msmt.cz/ministerstvo/koncepce-podpory-rozvoje-nadani-a-pece-o-nadane-na-obdobi

Kvasz, L. (2015). Inštrumentálny realizmus. Pavel Mervart.

Mareš, J., \& Ouhrabka, M. (1992). Žákovo pojetí učiva. Pedagogika, 42(1), 83-94.

Mareš, J., \& Ouhrabka, M. (2001). Dětské interpretace světa a žákovo pojetí učiva. In J. Čáp, \& J. Mareš, Psychologie pro učitele (s. 411-440). Portál.

Materna, P. (1995). Svět pojmů a logika. Filosofia.

Materna, P. (1997). Teorie pojmů: bolzanovská a množinová tradice. Filosofický časopis, 45(4), 547-557.

Myers, B., \& Jones, L. (2018). Effective use of field trips in educational programming: A three stage approach. IFAS Extension, University of Florida. http://edis.ifas.ufl.edu/wc054

Nohavová, A. (2018). Didaktika psychologie: od cíle výuky k jeho realizaci. Pedagogická fakulta JU v Českých Budějovicích.

Novak, J. D. (1990). Concept mapping: A useful tool for science education. Journal of Research in Science Teaching, 27(10), 937-949.

Novak, J. D. (2010). Learning, creating, and using knowledge: Concept maps as facilitative tools in schools and corporations. Journal of e-Learning and Knowledge Society, 6(3), 21-30.

Novak, J. D., \& Gowin, D. B. (1984). Learning how to learn. Cambridge University Press.

Novak, J.D. (1998). Learning, creating, and using knowledge: Concept maps as facilitative tools in schools and corporations. Lawrence Erlbaum: Associates, Inc.

Özdemir, G., \& Clark, D. B. (2007). An overview of conceptual change theories. Eurasia Journal of Mathematics, Science \& Technology Education, 3(4), 351-361. https://doi.org/10.12973/ejmste/75414 
Patrick, O. A. (2010). Effects of field studies on learning outcome in biology. Journal of Human Ecology, 31(3), 171-177. https://doi.org/10.1080/09709274.2010.11906312

Patton, M. Q. (1990). Qualitative evaluation and research methods (2nd ed.). Sage Publications, Inc., American Psychological Association, Washington.

Pauk, F. (1981). Didaktika geologických věd. SPN.

Pavlasová, L. (2014). Přehled didaktiky biologie. Univerzita Karlova, Pedagogická fakulta.

Pavlasová, L., Hrouda, L., Teodoridis, V., Andreska, J., Ř́íhová, D., Vančata, V., Novotný, P., Řezníček, J., \& Novotná, M. (2015). Př́rodovědné exkurze ve školní praxi. Univerzita Karlova, Pedagogická fakulta.

Piaget, J. (1972). Play, dreams and imitation in childhood. Routledge \& Kegan Paul.

Posner, G. J., Strike, K. A., Hewson, P. W., \& Gertzog, W. A. (1982). Accommodation of a scientific conception: Toward a theory of conceptual change. Science Education, 66(2), 211-227. http://www.fisica.uniud.it/URDF/laurea/idifo1/materiali/g5/Posner\%20et\%20al.pdf

Reiska, P., \& Soika, K. (2015). Suggestions for teacher education from concept mapping studies. Knowledge Management \&5 E-Learning: An International Journal (KM\&EL), 7(1), 149-161. https://doi.org/10.34105/j.kmel.2015.07.010

Rennie, L. J. (2007). Learning outside of school. In S. K. Abell \& N. G. Lederman (Eds.), Handbook of research on science education. Mahwah, New Jersey: Erlbaum. p. 175-185. https://doi.org/10.4324/9780203097267

Ruiz-Primo, M. A., \& Shavelson, R. J. (1996). Problems and issues in the use of concept maps in science assessment. Journal of Research in Science Teaching, 33(6), 569-600.

Slavík, J., Janík, T., Najvar, P., \& Knecht, P. (2017). Transdisciplinární didaktika o učitelském sdílení znalostí a zvyšování kvality výuky např́č obory. Masarykova univerzita.

Storksdieck, M. (2006). Field trips in environmental education. Berliner Wissenschafts-Verlag.

Strike, K. A., \& Posner, G. J. (1982). Conceptual change and science teaching. European Journal of Science Education, 4(3), 231-240. https://doi.org/10.1080/0140528820040302

Strautmane, M. (2012). Concept map-based knowledge assessment tasks and their scoring criteria: An overview. In A. J. Cañas, J. D. Novak, \& J. Vanhear (Eds.), Concept maps: theory, methodology, technology. Proceedings of the Fifth International Conference on Concept Mapping (pp. 80-88). University of Malta. http://cmc.ihmc.us/cmc/cmcproceedings.html

Švaříček, R., Sed’ová, K., Janík, T., Kaščák, O., Miková, M., Nedbálková, K., Novotný, P., Sedláček, M., \& Zounek, J. (2007). Kvalitativní výzkum v pedagogických vědách: pravidla hry. Portál.

Torkar, G., Krnel, D., Chocholoušková, Z., \& Humby, P. (2017). Using a concept map to evaluate pedagogical value of a serious game about plant ecology. In D. Krnel (Ed.), Tealeaf Academic book (pp. 77-92). University of Ljubljana. https://www.pef.uni-lj.si/fileadmin/Datoteke/Zalozba/e-publikacije/TEALEAF_2017.pdf

Tytler, R. (2002). Teaching for understanding in science: Student conceptions of research, and changing views of Learning. Australian Science Teachers Journal, 48(3), 14-21.

Van Zele, E., Lenaerts, J., \& Wieme, W. (2004). Improving the usefulness of concept maps as a research tool for science education. International Journal of Science Education, 26(9), 1043-1064.

https://doi.org/10.1080/1468181032000158336

Vaňková, P. (2014). Pojmové mapy ve vzdělávání. Karolinum.

Vonková, H. (2011). Mimotřídní a mimoškolní organizační formy. In A. Vališová, \& H. Kasíková (Eds.), Pedagogika pro učitele (s. 181-182). 2. rozšířené a aktualizované vydání. Grada.

Vygotskij, L.S. (1978). Mind in society: The development of higher psychologicalprocesses. Harvard University Press.

Vosniadou, S. (2007). Conceptual change and education. Human Development, 50, 47-54.

https://doi.org/10.1159/000097684

Vosniadou, S. (2008). International handbook of research on conceptual change. Routledge, University of Athens. https://doi.org/10.4324/9780203874813

Wallace, J. D., \& Mintzes, J. J. (1990). The concept map as a research tool: Exploring conceptual change in biology. Journal of Research in Science Teaching, 27(10), 1033-1052.

Whitesell, E. R. (2015). A Day at the museum: The impact of field trips to informal science education institutions on middle school science achievement. Institute for Education and Social Policy. https://doi.org/10.1002/tea.21322

Yassir, M. M., \& Abeer, A. A. (2014). The impact of field trips on students' creative thinking and practices in arts education. Journal of American Science, 10(1), 46-50. 